\title{
Financial Services Used by Small Businesses: Evidence from the 1998 Survey of Small Business Finances
}

Marianne P. Bitler, Alicia M. Robb, and John D. Wolken, of the Board's Division of Research and Statistics, prepared this article. Courtney Carter, Doug Rohde, and Emily Rosenberg provided research assistance.

Small businesses-firms having fewer than 500 employees - are an integral part of the U.S. economy. They account for about half of private-sector output, employ more than half of private-sector workers, and provide about three-fourths of net new jobs each year. ${ }^{1}$

Newly available data from the Survey of Small Business Finances provide a detailed look at these firms - their characteristics and their use of credit and other financial services. The survey is the most comprehensive source of such information; no other source provides the breadth and detail of information for a nationally representative sample of small businesses.

Since the first small business survey in 1987, the financial landscape in which these firms operate has changed markedly. Restrictions on interstate branching and banking have been relaxed, and certain financial institutions are now permitted to offer a wider range of financial services. Technological innovations (such as the use of small-business credit-scoring models) and structural changes in the financial services industry (such as consolidation of banking and thrift institutions) have also contributed to the alteration. By comparing the newest survey data with results from earlier surveys in 1987 and 1993, policymakers and researchers will be able to assess the effects these marketwide changes may have had on the use of financial services by small businesses and on the competitive financial environment in which they operate. ${ }^{2}$

1. U.S. Small Business Administration, Office of Advocacy, Small Business FAQ, December 2000. For more information on small businesses' role in the economy, see U.S. Small Business Administration, Office of Advocacy, 1998 State of Small Business, chap. 2 (http:// www.sba.gov/advo/stats/)

2. The earlier surveys were called National Surveys of Small Business Finances. For more information about the 1987 survey, see
The latest survey gathered data for fiscal year 1998 from 3,561 firms selected to be representative of small businesses operating in the United States in December 1998. ${ }^{3}$ The data show that in 1998 , as in 1987 and 1993, most small businesses were very small (nearly two-thirds had fewer than five employees) and most (nearly four-fifths) were located in urban areas. ${ }^{4}$ Ownership characteristics had changed somewhat since 1993-nearly 15 percent were owned by minorities (up from nearly 12 percent in 1993), and more than 24 percent were owned by women (up from nearly 21 percent in 1993).

Commercial banks continued to be the supplier most commonly used by small businesses for financial services other than leasing, brokerage services, and trust and pension services. Finance companies and leasing companies were also important suppliers of credit and financial management services, especially for the largest firms. The likelihood of using a service increased with firm size, as did the likelihood of using each type of supplier except thrifts and family and individuals.

In the 1998 survey, 55 percent of small businesses reported outstanding loans, capital leases, or lines of credit at year-end, compared with 59 percent in the 1993 survey. Credit use increased strongly with firm size: About 33 percent of the smallest firms had outstanding loans, capital leases, or lines of credit, compared with about 92 percent of the largest firms.

Gregory E. Elliehausen and John D. Wolken, "Banking Markets and the Use of Financial Services by Small and Medium-Sized Businesses," Federal Reserve Bulletin, vol. 76 (October 1990), pp. 801-17. For more information about the 1993 survey, see Rebel A. Cole and John D. Wolken, "Financial Services Used by Small Businesses: Evidence from the 1993 National Survey of Small Business Finances," Federal Reserve Bulletin, vol. 81 (July 1995), pp. 629-67. For more information on the earlier surveys, see the Board's public web site (http://www.federalreserve.gov/pubs/oss/oss $3 /$ nssbftoc.htm).

3. Firms whose fiscal years ended between July 1 and December 31, 1998, reported data for fiscal year 1998; otherwise, firms reported data for fiscal year 1999. For simplicity, results from the 1998 survey are referred to in this article as 1998 data.

4. The data cited in this article are weighted to adjust for differences in sampling and response rates. They reflect population rather than sample measures. For further information on the survey process, see the appendix. 
Although the percentage of small businesses with outstanding loans, capital leases, or lines of credit was about the same in 1998 as in 1993, the types of credit used changed somewhat over the intervening period: The percentage that had outstanding vehicle loans, equipment loans, trade credit, and other loans declined somewhat, whereas the percentage that had outstanding mortgages or used personal and business credit cards for business purposes increased.

The 1998 data are still being edited and are therefore subject to revision. However, the descriptive findings reported here are likely to be robust. ${ }^{5}$ Once the data are final, the database will allow for rigorous analysis that takes into account characteristics of the businesses, their owners, and existing markets. Researchers will be able to study many aspects of small business finance, including, for example, how the proximity of financial institutions affects the mix of financial products the firm uses, which firm and owner characteristics affect the ability of small businesses to obtain credit, and how lending patterns vary with these characteristics. ${ }^{6}$

\section{ECONOMIC AND FINANCIAL SERVICES ENVIRONMENT}

The financial services industry and the economic climate were considerably different in 1998 than in 1993. Over the period between the surveys, the intense consolidation activity that had begun early in the decade reduced the number of financial institutions operating in the United States more than 20 percent. ${ }^{7}$ Indeed, three of the largest bank consolidations to that point-BankAmerica and NationsBank, Wells Fargo and Norwest, and Banc One and First Chicago NBD-occurred in 1998. Cross-industry merger activity was also strong over the period as the traditional boundaries between three important types of firms that make up the financial services industrydepository institutions, securities firms, and insurance companies-continued to erode. A notable

5. The remaining data editing work primarily involves imputing missing values. Because the discussion in this article is based on questions that were answered by the vast majority of respondents, the statistics presented here, although based on preliminary data, will not differ much from those based on final data. The differences reported in this article are based only on the descriptive statistics presented. Standard errors for the differences have not yet been calculated, so it is uncertain whether the differences are statistically significant.

6. A final data set will be available to the public through the Board's public web site by summer 2001 (http://www.federalreserve. gov/pubs/oss/oss3/nssbftoc.htm).

7. The number of commercial banks and thrifts operating in the United States declined from 13,090 in 1993 to 10,305 in 1998 .
1. Most important problem facing small businesses in 1998 , distributed by size of business

Percent

\begin{tabular}{|c|c|c|c|}
\hline \multirow{2}{*}{ Problem } & \multicolumn{3}{|c|}{ Number of employees ${ }^{1}$} \\
\hline & 9 or fewer & $10-49$ & $50-499$ \\
\hline $\begin{array}{l}\text { Competition (from larger, } \\
\text { international, or Internet }\end{array}$ & & & \\
\hline companies) & 11.0 & 12.5 & 12.3 \\
\hline Quality of labor & 10.1 & 24.3 & 25.2 \\
\hline Cost or availability of labor & 3.2 & 6.5 & 12.6 \\
\hline Poor sales $\ldots \ldots \ldots \ldots \ldots$ & 7.6 & 6.4 & 7.3 \\
\hline Financing and interest rates . & 6.9 & 6.4 & 3.7 \\
\hline Government regulations and & & & 80 \\
\hline $\begin{array}{r}\text { red } t \\
\text { Taxes .. }\end{array}$ & $\begin{array}{l}0.9 \\
7.2\end{array}$ & 5.8 & $\begin{array}{l}0.0 \\
3.3\end{array}$ \\
\hline Other & 47.1 & 32.2 & 27.6 \\
\hline
\end{tabular}

NoTE. In this and subsequent tables, unless otherwise noted, the data are weighted to adjust for differences in sampling and response rates; the weighted data reflect population rather than sample measures. See the appendix for more information.

Also in this and subsequent tables, distributions may not sum to 100 percent because of rounding or because, in a few cases, values for some variables are missing.

1. Sum of number of owners working in the business and number of employees (full- and part-time) working in the business.

example was the 1998 merger between Citicorp, a bank holding company, and Travelers, an insurance and securities firm. ${ }^{8}$

In 1998, the economy was in the seventh year of a sustained economic expansion. Unemployment was just under 5 percent, the consumer price index (CPI) rose 1.6 percent, the gross domestic product (GDP) grew 4.4 percent, and productivity in the business sector increased 2.7 percent. In 1993, the economy was in the early stages of an expansion following two years of recession; unemployment was nearly 7 percent, the CPI and GDP each increased 2.7 percent, and business-sector productivity grew just one-half of 1 percent. ${ }^{9}$

According to the 1998 survey, labor issues (the quality, cost, and availability of labor) were the greatest concern for small businesses, particularly among the largest firms (table 1). Another commonly mentioned concern was competition from larger, international, or Internet firms. Other important problemsalthough mentioned less often-were financing and

8. The diminishing separation among these three types of firms culminated in passage in 1999 of the Financial Services Modernization Act, which removed most of the remaining barriers. See Group of Ten, "Report on Consolidation in the Financial Sector" (Paris: Organisation for Economic Co-operation and Development, January 2001) (http://www.oecd.org/eco/Group-of-Ten/report-onconsolidation.htm).

9. Economic conditions in 1998 were much more similar to those faced by the businesses surveyed in 1987, when the economy was well into the 1982-90 expansion. Council of Economic Advisors, Economic Report of the President, January 2001 (http://w3.access.gpo. gov/eop). 
interest rates, government regulations, taxes, and poor sales.

The primary concerns of small businesses were markedly different in $1993 .{ }^{10}$ In that survey, health care and health insurance were cited most often, followed by general U.S. business conditions-two issues that received much less attention in 1998. The other problems mentioned most frequently in 1993 were financing and interest rates; profits, cash flow, expansion, and sales; and taxes.

\section{CHARACTERISTICS OF SMALL BUSINESSES}

Along with information on the availability and use of credit and other financial services by small businesses, the 1998 Survey of Small Business Finances collected information on firm characteristics, including number of employees; number of owners; organizational form; location; use of computers; standard industrial classification; credit history; sex, race, and ethnicity of the owner(s) with the majority share of the firm; and income and balance sheet data. ${ }^{11}$ Also collected was information on each firm's primary owner (defined as the owner with the largest ownership share if the firm had more than one owner), including age, education, experience in business, ownership share, credit history, personal net worth, home ownership, and home equity.

Business size is measured in three ways: number of employees, fiscal year sales, and year-end assets. In terms of employment, most small businesses in 1998 were very small: About 64 percent had fewer than five employees, and just over 83 percent had fewer than ten employees (table 2). ${ }^{12}$ In terms of sales and assets, the businesses were similarly small: About 40 percent had fiscal year sales of less than $\$ 100,000$, and just over 61 percent had year-end assets of less than $\$ 100,000$. This general pattern is similar to findings from the 1993 survey.

10. The questions were worded slightly differently. The 1998 survey asked, "What is the single most important problem facing your business today?" and the 1993 survey asked, "What do you think will be the most important issue affecting your firm over the next twelve months?"

11. An important objective of the survey was to provide data to examine credit access by different firm and owner characteristics, including race and ethnicity. Because minority-owned businesses constitute a small proportion of the population of small businesses, the sample was designed to overrepresent minority-owned firms. As a result, the sample included sufficient numbers of observations to permit comparisons between minority-owned and other types of small businesses. For details, see the appendix.

12. Number of employees includes owners working in the business and both full- and part-time employees.
A business may organize as a corporation (S-type or C-type), a partnership, or a sole proprietorship. ${ }^{13}$ In 1998, the most common organizational form for small businesses was the sole proprietorship, accounting for nearly 50 percent of the firms. About 24 percent were organized as $\mathrm{S}$ corporations, about 20 percent as C corporations, and only 7 percent as partnerships.

The primary activity of 43 percent of the businesses (as classified according to the standard industrial classification (SIC) system used by the U.S. government) was business or professional services. An additional 19 percent were in retail trade.

Just over 22 percent of the firms had been in business under at least one of the current owners for less than five years (firm age less than five years), and another 23 percent had been in business five to nine years. More than 22 percent had been in business twenty years or more. Average firm age (not shown in the table) was 13.3 years, slightly less than the average firm age in 1993 of 14.5 years.

The firms were dispersed across the country, with nearly 19 percent located in the Northeast, about 27 percent in the West, almost 22 percent in the Midwest, and nearly 33 percent in the South. The vast majority (nearly 80 percent) had their main offices in urban areas, and the primary sales area for nearly all firms (more than 95 percent) was the United States.

\section{Race, Ethnicity, and Sex of Majority Owners}

A firm was classified as being owned by individuals of a specific race, ethnic group, or sex if more than

13. The organizational forms have different rules about liability and taxes. Sole proprietors receive all the income from the business and bear full liability for its obligations. Partnerships have more than one owner; like sole proprietors, the owners receive all the income from the business and, in general, are fully liable for its obligations. Corporations are separate legal entities, and the owners' liability is limited to the amount of their original equity investment. The primary difference between the two types of corporations is how they are taxed: $\mathrm{S}$ corporations are not subject to corporate income tax, whereas $\mathrm{C}$ corporations are. S corporations are legally constrained to have more than seventy-five shareholders, are restricted to one class of stock, and must pass all firm income to the owners at the end of each fiscal year. During the 1990s, two other organizational forms gained legal status in many states: the limited liability corporation (LLC) and the limited liability partnership (LLP). LLCs have many characteristics of partnerships but have the limited liability of corporations; LLPs are partnerships in which an investor's liability is limited to his or her initial investment. LLCs may file taxes as a partnership, a corporation, or a sole proprietorship; LLPs may file taxes as a partnership or a corporation. For this survey, LLCs and LLPs were classified according to how they chose to file their taxes. The 1998 data imply that in the survey universe, 0.2 percent of the firms were LLCs and 1.8 percent were LLPs at year-end 1998. 
2. Number and proportion of population of small businesses in survey sample, distributed by selected category of firm, 1998

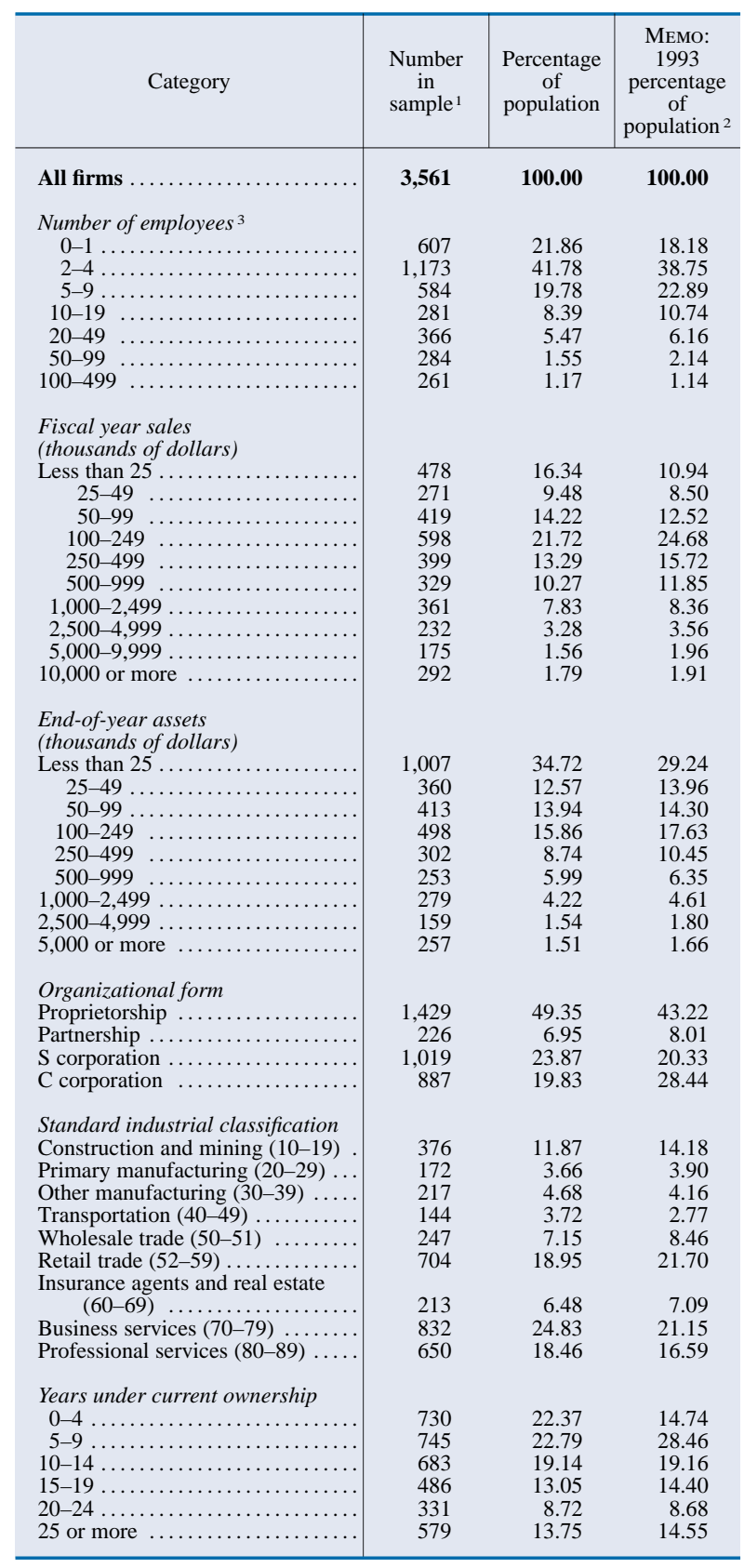

1. Numbers are unweighted. For some categories, numbers in sample do not sum to the sample total because some firms responded "Do not know" or declined to respond.

2. The percentages reported here are final data and may differ slightly from the preliminary data for 1993 reported in Cole and Wolken, "Financial Services Used by Small Businesses," 1995.

50 percent of the firm was owned by such individuals. About 15 percent of small businesses in 1998 were minority-owned (that is, owned by nonwhite or Hispanic individuals), compared with about 12 per-

\section{2.-Continued}

\begin{tabular}{|c|c|c|c|}
\hline Category & $\begin{array}{c}\text { Number } \\
\text { in } \\
\text { sample }^{1}\end{array}$ & $\begin{array}{l}\text { Percentage } \\
\text { of } \\
\text { population }\end{array}$ & $\begin{array}{c}\text { Мемо: } \\
1993 \\
\text { percentage } \\
\text { of } \\
\text { population }\end{array}$ \\
\hline \multicolumn{4}{|l|}{ Census region of main office } \\
\hline Northeast ............... & 595 & 18.90 & 22.31 \\
\hline New England & 155 & 5.21 & 6.94 \\
\hline Middle Atlantic & 440 & 13.69 & 15.37 \\
\hline Midwest & 770 & 21.80 & 24.13 \\
\hline East North Central & 485 & 14.56 & 15.96 \\
\hline West North Central & 285 & 7.24 & 8.17 \\
\hline South & 1,225 & 32.71 & 29.48 \\
\hline South Atlantic & 641 & 16.88 & 14.84 \\
\hline East South Central & 202 & 5.47 & 4.55 \\
\hline West South Central & 382 & 10.35 & 10.09 \\
\hline West & 971 & 26.59 & 24.08 \\
\hline Mountain & 238 & 6.63 & 5.81 \\
\hline Pacific ... & 733 & 19.96 & 18.27 \\
\hline \multicolumn{4}{|l|}{ Urbanization at main office } \\
\hline Urban $\ldots \ldots \ldots \ldots \ldots \ldots$ & 2,782 & 79.91 & 78.88 \\
\hline Rural & 779 & 20.09 & 21.12 \\
\hline \multicolumn{4}{|l|}{ Number of offices } \\
\hline One $\ldots . . \cdots \cdots$ & 2,839 & 87.75 & 84.35 \\
\hline Two ............. & 379 & 8.55 & 10.73 \\
\hline Three or more & 341 & 3.63 & 4.92 \\
\hline \multicolumn{4}{|l|}{ Sales area } \\
\hline Primarily within U.S. & 3,355 & 95.43 & $\ldots$ \\
\hline International or global & 204 & 4.51 & \\
\hline \multicolumn{4}{|l|}{ Owners' participation } \\
\hline Owner management & 3,188 & 92.33 & 86.00 \\
\hline Hired management .. & 369 & 7.52 & 14.00 \\
\hline \multicolumn{4}{|l|}{$\begin{array}{l}\text { Race, ethnicity, and sex } \\
\text { of majority owners }\end{array}$} \\
\hline Nonwhite or Hispanic . & 756 & 14.60 & 11.62 \\
\hline Non-Hispanic white & 2,790 & 84.88 & 88.38 \\
\hline White & 3,033 & 90.12 & 92.52 \\
\hline Black & 273 & 4.12 & 2.91 \\
\hline Asian or Pacific Islander & 214 & 4.38 & 3.44 \\
\hline $\begin{array}{l}\text { American Indian or } \\
\text { Alaska Native }\end{array}$ & 24 & 0.81 & 1.13 \\
\hline Hispanic & 260 & 5.59 & 4.27 \\
\hline Non-Hispanic & 3,292 & 94.10 & 95.73 \\
\hline Female. & 796 & 24.32 & 20.61 \\
\hline Male ............. & 2,609 & 71.88 & 73.92 \\
\hline $\begin{array}{l}\text { Ownership equally divided } \\
\text { by sex }\end{array}$ & 147 & 3.67 & 5.47 \\
\hline
\end{tabular}

3. Number of owners working in the business plus number of full- and part-time employees. For the 1993 and 1987 surveys, the number of employees was calculated as the sum of owners working in the business plus full-time employees plus one-half of part-time employees; in the 1998 survey, no differentiation was made between full- and part-time employees. To make the data for 1998 and 1993 comparable, the 1993 numbers have been recalculated as the sum of owners working in the business, full-time employees, and part-time employees; therefore, the numbers presented here differ from those reported in Cole and Wolken, "Financial Services Used by Small Businesses," 1995.

.. . Question not asked in 1993.

cent in 1993. Between 1993 and 1998, the proportion of black-owned firms increased from about 3 percent to about 4 percent. Over the same period, the proportion of Hispanic-owned firms increased from 4 percent to 6 percent and the proportion of Asian-owned firms, from 3 percent to 4 percent. Ownership by 
3. Percentage of small businesses that used computers, by selected category of firm, 1998

\begin{tabular}{|c|c|c|c|c|}
\hline \multirow{2}{*}{ Category } & \multirow{2}{*}{ Used computers } & \multicolumn{3}{|c|}{ Used computers for specific tasks ${ }^{2}$} \\
\hline & & Internet/WWW access & Banking & Administration \\
\hline All firms & 76.3 & 59.0 & 15.2 & 73.9 \\
\hline Number of employees ${ }^{1}$ & & & & \\
\hline $\begin{array}{l}0-4 \ldots \ldots \ldots \ldots \ldots \\
5 \text { or more } \ldots \ldots \ldots \ldots \ldots\end{array}$ & $\begin{array}{l}70.8 \\
88.5\end{array}$ & $\begin{array}{l}53.8 \\
70.6\end{array}$ & $\begin{array}{l}13.6 \\
18.8\end{array}$ & $\begin{array}{l}68.0 \\
86.8\end{array}$ \\
\hline Fiscal year sales (thousands of dollars) & & & & \\
\hline Less than 100 ......................... & 62.7 & 48.1 & 11.6 & 60.3 \\
\hline 100 or more $\ldots \ldots \ldots \ldots \ldots \ldots \ldots$ & 85.6 & 66.6 & 17.7 & 83.2 \\
\hline End-of-year assets (thousands of dollars) & & & & \\
\hline Less than $100 \ldots \ldots \ldots \ldots \ldots \ldots$ & 70.6 & 54.0 & 12.7 & 68.0 \\
\hline 100 or more . & 85.6 & 67.2 & 19.2 & 83.7 \\
\hline Years under current ownership & & & & \\
\hline $0-4 \ldots \ldots \ldots \ldots \ldots \ldots \ldots \ldots$ & 78.4 & 62.7 & 16.7 & 75.9 \\
\hline $5-9 \ldots \ldots \ldots \ldots \ldots \ldots \ldots$ & 78.6 & 64.1 & 16.6 & 75.7 \\
\hline 10 or more & 74.4 & 55.6 & 14.1 & 72.2 \\
\hline
\end{tabular}

American Indians or Alaska Natives remained at about 1 percent. ${ }^{14}$

The proportion of firms that were more than 50 percent owned by men declined somewhat, from about 74 percent in 1993 to about 72 percent in 1998 , and the proportion that were more than 50 percent owned by women rose from about 21 percent to about 24 percent. The proportion equally owned by men and women fell nearly 2 percentage points, to 4 percent.

The survey data suggest that female- and minorityowned firms share some characteristics that distinguish them from male- and white-owned firms (table A.1). By all three measures of size, femaleand minority-owned firms appear to be smaller than male- and white-owned firms. They also appear to be younger, more likely to be sole proprietorships, and less likely to be corporations. These differences are similar to the findings in 1993. The differences in organizational type may simply reflect that minorityowned and female-owned firms tend to be younger and smaller than non-minority-owned and maleowned firms-and younger and smaller firms are

14. By U.S. government convention, race and ethnicity are separate categories. Thus, firm owners can be Hispanic (or non-Hispanic) and of any race. The 1998 survey asked about Hispanic ethnicity and race in two separate questions. Firms were asked if the owner (for singleowner firms) or owners of more than 50 percent of the firm (for multi-owner firms) were of Hispanic, Latino, or Spanish descent. Firms answering "yes" were classified as Hispanic-owned. Firms were then asked to specify the race of the owner (for single-owner firms) or the races(s) of the owner(s) of more than 50 percent of the firm (for multi-owner firms) from the following list: white; black; Asian, including Native Hawaiian or other Pacific Islander; and American Indian or Alaska Native. In this article, the category minority-owned indicates ownership by individuals who are nonwhite or Hispanic or both. The few firms reporting that their ownership shares were equally split between minority and non-minority individuals were classified as non-minority-owned. more likely to organize as sole proprietorships or partnerships rather than as corporations.

\section{Computer Use within the Firm}

More than three-fourths of the firms used computers in their businesses in 1998 (table 3) (this question was not asked in the earlier surveys). Use varied somewhat by size, with larger firms being more likely than smaller firms to use computers. For example, 89 percent of firms with more than four employees used computers for business purposes, compared with 71 percent of firms with four or fewer employees. Similarly, 86 percent of firms with sales of $\$ 100,000$ or more used computers, compared with 63 percent with sales of less than $\$ 100,000$. Firms used computers for a variety of purposes: 59 percent used them to access the Internet; about 15 percent for banking; and about 74 percent for inventory management or bookkeeping.

\section{TYPES OF FINANCIAL SERVICES USED BY SMALL BUSINESSES}

Businesses were asked which of thirteen financial services they used at up to twenty different institutions. ${ }^{15}$ The services can be grouped into several categories: liquid asset services (business checking

15. For this article, use of a financial service was measured by the percentage of small businesses that used a specific type or source of service. Data on use based on dollar amounts or numbers of accounts will be available at a later date. However, previous analysis has shown that conclusions based on dollar amounts, or on number of accounts, are usually qualitatively very similar to conclusions based on the 
or savings accounts); credit lines, loans, and capital leases (lines of credit, mortgages, motor vehicle loans, equipment loans, capital leases, and "other" loans); and financial management services (transaction, cash-management, credit-related, brokerage, and trust and pension services). Owner loans, credit cards, and trade credit are discussed separately and are not included in the tabulations for "any financial service," as no information was collected about the providers of these financial services.

\section{Any Financial Service}

Nearly all small businesses (about 96 percent) used at least one financial service in 1998, essentially the same finding (97 percent) as in 1993 (table 4). In general, use increased with firm size, and almost all firms with five or more employees, or with sales or assets of at least $\$ 250,000$, used some financial service during the year. About 9 percent of firms with fewer than two employees used no financial service in 1998.

Proprietorships and partnerships were less likely than corporations to use a financial service. The difference may be due to the tendency of many proprietorships and some partnerships to commingle business and personal finances; for example, the owners may use personal savings and checking accounts for business purposes. ${ }^{16}$ Also, young firms (less than five years old), firms with single offices, and black-, Hispanic-, and female-owned firms were less likely than other firms to use a financial service.

\section{Checking and Savings}

Most small businesses (94 percent) had a checking account at the end of 1998, the same percentage as used any liquid asset account (checking or savings). ${ }^{17}$

percentages of firms using one or more service or source. See Rebel A. Cole, John D. Wolken, and R. Louise Woodburn, "Bank and Nonbank Competition for Small Business Credit: Evidence from the 1987 and 1993 National Surveys of Small Business Finances," Federal Reserve Bulletin, vol. 82 (November 1996), pp. 983-95.

16. Respondents were asked to count as a business service any personal account that was used at least 50 percent of the time for business purposes. Most of the firms that reported using no financial service were extremely small, and it is possible that those firms' owners used personal accounts for business purposes, but did so less than 50 percent of the time.

17. Checking accounts were defined as accounts with unlimited check-writing privileges, including share draft accounts; money market accounts, including money market deposit accounts, were considered checking accounts only if they offered unlimited check-writing privileges. Savings accounts were defined as passbook savings, credit union share accounts, certificates of deposits, and other time deposits;
Because a checking account, including a share draft account, is a vehicle for paying suppliers and depositing sales receipts, it is not surprising that the reported use of "any service" (96 percent) nearly matches the reported use of "any liquid asset account." The data on business savings accounts, however, reveal some interesting differences across firms. Having such an account was highly correlated with firm size. For example, about one-fifth of firms with fewer than ten employees had a business savings account at the end of 1998, compared with more than one-third of firms with ten or more employees. White-owned firms were the most likely to have a business savings account, followed by Hispanic- and Asian-owned firms; blackowned firms were the least likely to have a business savings account. Female-owned firms were more likely than male-owned firms to have such an account. Having such an account varied little by industry.

\section{Credit Lines, Loans, and Capital Leases}

Overall, the incidence of credit lines, outstanding loans, and outstanding capital leases declined between year-end 1993 and year-end 1998 (from 59 percent of firms to 55 percent). Declines were recorded for vehicle loans (which fell from 25 percent to 21 percent), equipment loans (15 percent to 10 percent), and "other" loans (13 percent to 10 percent). ${ }^{18}$ Capital leases were about as common in 1998 as in 1993, and the incidence of credit lines and mortgages increased.

The slight increase in the percentage of firms with lines of credit (28 percent in 1998 compared with 26 percent in 1993) may have been the result of an increase in commercial banks' use of credit-scoring models. Alternatively, the increase may have been due to differences in the economic environment; as noted earlier, in 1993 the economy was in the early stages of an expansion following a period during

also considered savings accounts were money market accounts that were limited in either the number or the amount of checks that could be written. In comparison with small businesses, 91.5 percent of households had some type of transaction account (checking account, saving account, money market deposit account, money market mutual fund, or call account at a brokerage) in 1998, according to the 1998 Survey of Consumer Finances. For more information, see Arthur B. Kennickell, Martha Starr-McCluer, and Brian J. Surette, "Recent Changes in U.S. Family Finances: Results from the 1998 Survey of Consumer Finances," Federal Reserve Bulletin, vol. 86 (January 2000), pp. 1-29.

18. "Other" loans are any loans that could not be classified as credit lines, capital leases, mortgages used for commercial purposes, motor vehicle loans, or equipment loans (generally, unsecured term loans). 
which a drop in commercial real estate values erased equity against which many firms might have borrowed. The greater reliance on mortgages in 1998 (13 percent compared with 8 percent in 1993) may reflect recovery of the commercial real estate market.

As with checking and savings accounts, the incidence of credit lines, loans, and capital leases increased with firm size: More than 90 percent of the largest firms (100-499 employees) had one of these types of credit at the end of 1998, compared with fewer than 50 percent of very small firms (fewer than five employees). Corporations were more likely than other types of firms to have credit lines, loans, and capital leases. Firms in the services industries (business and professional) were generally less likely than firms in other industries to have these types of credit, perhaps because they require less inventory and equipment.

The incidence of credit also varied somewhat with firm age. The percentage of firms that had credit lines, loans, or leases was smallest for those that were less than five years old (51 percent), followed by those that were more than twenty-five years old (53 percent). The finding for the youngest firms is consistent with the observation that depository institutions typically require that borrowers have several years of financial history to qualify for credit.

The incidence of credit lines, loans, and capital leases also varied somewhat with owner characteristics. At year-end 1998, fewer than 50 percent of female-, black-, and Asian-owned firms had one of these forms of credit, compared with roughly 55 percent of male- and white-owned firms. By specific loan type, white-owned firms were generally more likely than nonwhite-, Hispanic-, or female-owned firms to have lines of credit, mortgages, vehicle loans, and equipment loans. Black-owned firms were the most likely to have capital leases and "other" loans. Some of the differences by owner race, ethnicity, and sex may be attributable to differences in firm characteristics, such as size. Attribution of these univariate differences to owner race, firm size or age, or other variables is a topic for additional research. ${ }^{19}$

\section{Financial Management Services}

Financial management services include transaction services, cash-management services, credit-related

19. For research on this topic using multivariate analysis, see, for example, Ken S. Cavalluzzo, Linda C. Cavalluzzo, and John D. Wolken, "Competition, Small Business Financing, and Discrimination: Evidence from a New Survey," Journal of Business (forthcoming). services, trust and pension services, and brokerage services. ${ }^{20}$ Fifty percent of small businesses used at least one financial management service in 1998, compared with 37 percent in 1993 . They were more likely to use transaction and trust services in 1998, compared with 1993, and equally likely to use cashmanagement and brokerage services. The incidence of credit-related services fell from about 5 percent of firms in 1993 to only 3 percent in 1998, a decline consistent with the overall decline in the incidence of credit lines, loans, and capital leases described earlier.

The most widely used financial management service in 1998, reported by about two-fifths of all firms, was transaction services. Trust and pension services were used by only about one in eight firms, and cash-management services by only one in twenty. As was the case for other financial services, the use of financial management services increased with firm size. For the smallest firms (as measured by number of employees), only 34 percent used at least one financial management service, and only a very small percentage used any financial management service other than transaction services. In contrast, about 85 percent of the largest firms used at least one financial management service; the most commonly used was transaction services, followed by cashmanagement services and trust and pension services. Brokerage services were used mainly by the larger firms, but by only about one in twelve.

A smaller proportion of proprietorships used financial management services relative to firms with other organizational forms; they may have less need for these services because they tend to be small and more likely than other types of firms to commingle personal and business accounts.

Firms differed in their use of financial management services by the minority status of and, to a somewhat lesser extent, by the sex of the majority owners. Black-, Hispanic-, and female-owned firms were less likely than white-, non-Hispanic-, and male-owned firms to use such services. Asian-owned firms were the most likely to do so (more than two-thirds used at least one financial management service in 1998). The differences were due largely to differences in the use

20. Transaction services cover the provision of paper money and coins, the processing of credit card receipts, the collection of night deposits, and wire transfers. Cash-management services include the provision of sweep accounts, zero-balance accounts, lockbox services, and other services designed to automatically invest liquid funds in liquid, interest-bearing assets. Credit-related services are the provision of bankers acceptances, letters of credit, sales finance, and factoring. Trust and pension services consist of the provision of 401(k) plans, pension funds, business trusts, and securities safekeeping. 
4. Percentage of small businesses using selected financial services, by selected category of firm, 1998 A. Any service; liquid asset accounts; and credit lines, loans, and capital leases

\begin{tabular}{|c|c|c|c|c|c|c|c|c|c|c|c|}
\hline \multirow{2}{*}{ Category } & \multirow{2}{*}{$\begin{array}{l}\text { Any } \\
\text { service }^{1}\end{array}$} & \multicolumn{3}{|c|}{ Liquid asset accounts $^{2}$} & \multicolumn{7}{|c|}{ Credit lines, loans, and capital leases } \\
\hline & & Any & Checking & Savings & Any & $\begin{array}{c}\text { Credit } \\
\text { line }\end{array}$ & Mortgage & Vehicle & $\begin{array}{c}\text { Equip- } \\
\text { ment }\end{array}$ & $\begin{array}{c}\text { Capital } \\
\text { lease }\end{array}$ & Other $^{3}$ \\
\hline All firms, 1998 & 96.18 & 94.43 & 94.04 & 22.20 & 55.09 & 27.71 & 13.29 & 20.55 & 10.18 & 10.59 & 9.92 \\
\hline All firms, 1993 & 97.03 & 96.21 & 95.81 & 24.35 & 59.13 & 25.71 & 7.83 & 25.28 & 14.84 & 10.25 & 12.74 \\
\hline \multicolumn{12}{|l|}{ Number of employees ${ }^{4}$} \\
\hline $0-1 \ldots \ldots \ldots \ldots \ldots$ & 91.02 & 86.41 & 85.33 & 16.37 & 32.79 & 13.42 & 6.55 & 12.80 & 3.77 & 3.29 & 5.82 \\
\hline $2-4$ & 95.86 & 94.34 & 94.10 & 19.45 & 49.80 & 20.83 & 12.45 & 16.89 & 8.25 & 7.42 & 9.35 \\
\hline $5-9$. & 99.37 & 99.05 & 98.79 & 23.38 & 68.53 & 34.08 & 16.21 & 26.92 & 14.52 & 14.26 & 9.19 \\
\hline $10-19$ & 100.00 & 99.86 & 99.86 & 35.86 & 78.01 & 50.59 & 19.89 & 32.63 & 13.97 & 23.19 & 14.67 \\
\hline $20-49$ & 100.00 & 100.00 & 100.00 & 36.01 & 83.84 & 59.07 & 21.10 & 31.98 & 22.96 & 21.71 & 20.14 \\
\hline $50-99$ & 100.00 & 97.77 & 97.77 & 30.07 & 86.87 & 62.67 & 26.25 & 34.47 & 20.25 & 31.75 & 20.86 \\
\hline $100-499$ & 100.00 & 100.00 & 100.00 & 36.87 & 92.04 & 74.81 & 18.84 & 29.85 & 24.69 & 27.71 & 22.81 \\
\hline \multicolumn{12}{|l|}{$\begin{array}{l}\text { Fiscal year sales } \\
\text { (thousands of dollars) }\end{array}$} \\
\hline Less than $25 \ldots \ldots \ldots$ & 82.99 & 76.62 & 74.96 & 11.84 & 26.76 & 9.11 & 7.93 & 5.80 & $2.37 *$ & $2.82 *$ & 6.41 \\
\hline $25-49 \ldots$ & 94.77 & 91.64 & 91.12 & 17.12 & 33.47 & 11.25 & 7.65 & 14.92 & $3.70 *$ & $2.36^{*}$ & $3.36^{*}$ \\
\hline $50-99$ & 97.97 & 97.07 & 96.96 & 18.10 & 45.94 & 15.20 & 9.69 & 14.02 & 5.76 & 7.73 & 8.96 \\
\hline $100-249$ & 99.34 & 98.29 & 98.29 & 19.06 & 56.25 & 22.48 & 14.70 & 19.98 & 11.50 & 11.31 & 10.29 \\
\hline $250-499$ & 99.82 & 99.75 & 99.75 & 23.36 & 67.09 & 36.82 & 13.04 & 25.89 & 12.00 & 11.29 & 11.31 \\
\hline $500-999$ & 99.57 & 99.57 & 99.07 & 30.26 & 74.02 & 41.74 & 18.64 & 30.49 & 16.45 & 19.81 & 10.44 \\
\hline $1,000-2,499$ & 100.00 & 100.00 & 100.00 & 37.58 & 78.34 & 51.48 & 21.15 & 37.15 & 16.30 & 17.81 & 17.79 \\
\hline $2,500-4,999$ & 100.00 & 99.03 & 99.03 & 45.48 & 94.59 & 68.80 & 22.65 & 37.26 & 23.68 & 18.60 & 12.40 \\
\hline $5,000-9,999$ & 100.00 & 99.09 & 99.09 & 37.56 & 88.68 & 75.74 & 16.52 & 37.91 & 20.26 & 24.77 & 22.35 \\
\hline 10,000 or more $\ldots \ldots$ & 100.00 & 100.00 & 100.00 & 36.71 & 88.95 & 81.36 & 18.87 & 30.22 & 25.40 & 23.67 & 17.62 \\
\hline \multicolumn{12}{|l|}{$\begin{array}{l}\text { End-of-year assets } \\
\text { (thousands of dollars) }\end{array}$} \\
\hline Less than $25 \ldots \ldots \ldots$. & 89.87 & 86.55 & 85.77 & 12.24 & 32.64 & 11.35 & 6.28 & 10.47 & 4.77 & 5.23 & 5.00 \\
\hline $25-49 \ldots$ & 98.65 & 96.81 & 96.69 & 19.57 & 49.60 & 22.83 & 6.79 & 19.63 & 6.27 & 8.21 & 6.43 \\
\hline 50-99 & 99.68 & 99.31 & 98.96 & 20.53 & 60.06 & 25.25 & 10.05 & 21.80 & 9.70 & 10.30 & 12.26 \\
\hline $100-249$ & 99.46 & 98.40 & 98.40 & 28.81 & 67.85 & 34.61 & 17.46 & 26.42 & 15.55 & 12.67 & 13.50 \\
\hline $250-499$ & 100.00 & 100.00 & 99.41 & 33.64 & 71.65 & 40.97 & 22.65 & 28.90 & 12.41 & 13.97 & 11.57 \\
\hline 500-999 & 100.00 & 99.40 & 99.40 & 36.44 & 88.54 & 56.01 & 33.86 & 33.70 & 18.32 & 21.23 & 19.72 \\
\hline $1.000-2,499$ & 100.00 & 98.79 & 98.79 & 36.02 & 81.15 & 55.84 & 25.03 & 33.48 & 20.69 & 18.87 & 13.65 \\
\hline $2,500-4,999$ & 100.00 & 100.00 & 100.00 & 37.45 & 93.09 & 81.32 & 26.18 & 31.71 & 20.78 & 34.42 & 17.00 \\
\hline 5,000 or more & 100.00 & 100.00 & 100.00 & 45.29 & 95.66 & 76.01 & 31.16 & 38.77 & 30.75 & 22.26 & 17.22 \\
\hline \multicolumn{12}{|l|}{ Organizational form } \\
\hline Proprietorship ... & 93.16 & 89.94 & 89.16 & 18.23 & 45.66 & 18.51 & 12.44 & 16.11 & 7.13 & 6.52 & 8.20 \\
\hline Partnership .. & 95.37 & 95.24 & 95.24 & 18.75 & 61.18 & 27.69 & 19.07 & 19.43 & 13.10 & 12.92 & 9.54 \\
\hline $\mathrm{S}$ corporation & 99.85 & 99.56 & 99.56 & 24.68 & 65.00 & 37.89 & 13.91 & 25.32 & 12.41 & 14.75 & 11.53 \\
\hline C corporation & 99.58 & 99.15 & 99.15 & 30.33 & 64.50 & 38.35 & 12.65 & 26.23 & 14.05 & 14.90 & 12.38 \\
\hline \multicolumn{12}{|l|}{ Standard industrial classification } \\
\hline Construction and mining (10-19) & 97.11 & 96.13 & 96.04 & 20.63 & 66.76 & 31.98 & 12.07 & 38.15 & 11.93 & 8.27 & 10.52 \\
\hline Primary manufacturing $(20-29)$ & 95.49 & 92.87 & 92.87 & 19.79 & 56.49 & 32.10 & 8.66 & 16.31 & 19.82 & 20.05 & 17.36 \\
\hline Other manufacturing (30-39) & 94.15 & 91.98 & 91.98 & 23.79 & 60.15 & 35.87 & 6.85 & 19.47 & 15.30 & 14.08 & 17.10 \\
\hline Transportation $(40-49) \ldots \ldots$ & 98.60 & 98.23 & 98.23 & 23.56 & 62.13 & 29.70 & 10.85 & 28.82 & 14.16 & 14.92 & 12.61 \\
\hline Wholesale trade $(50-51)$ & 99.12 & 96.71 & 96.71 & 21.36 & 64.28 & 47.26 & 12.15 & 27.85 & 9.81 & 10.47 & 10.47 \\
\hline Retail trade $(52-59) . .$. . & 96.84 & 95.85 & 95.75 & 18.45 & 54.11 & 25.19 & 17.45 & 17.87 & 7.66 & 6.39 & 10.26 \\
\hline \multicolumn{12}{|l|}{ Insurance agents and } \\
\hline real estate $(60-69)$ & 96.61 & 96.13 & 96.13 & 25.40 & 59.77 & 26.90 & 24.81 & 16.63 & 11.53 & 9.97 & 8.94 \\
\hline Business services $(70-79)$ & 94.48 & 92.41 & 91.18 & 22.82 & 49.53 & 22.41 & 12.12 & 18.16 & 8.85 & 10.60 & 7.73 \\
\hline Professional services $(80-89)$ & 96.04 & 93.23 & 92.95 & 25.47 & 47.99 & 23.86 & 10.97 & 13.39 & 9.16 & 13.13 & 8.51 \\
\hline \multicolumn{12}{|l|}{ Years under current ownership } \\
\hline $0-4 \ldots \ldots \ldots \ldots \ldots \ldots \ldots$ & 94.50 & 93.25 & 92.85 & 15.38 & 51.14 & 19.63 & 11.95 & 18.51 & 10.62 & 8.90 & 11.18 \\
\hline $5-9$ & 96.05 & 93.61 & 93.34 & 20.87 & 55.79 & 26.87 & 10.91 & 18.08 & 10.48 & 11.95 & 11.14 \\
\hline $10-14$ & 96.59 & 94.75 & 93.93 & 25.74 & 56.18 & 30.88 & 14.01 & 23.87 & 9.32 & 12.10 & 7.02 \\
\hline $15-19$ & 98.45 & 96.76 & 96.61 & 26.31 & 58.90 & 33.24 & 16.06 & 22.00 & 12.12 & 11.32 & 12.50 \\
\hline $20-24$ & 98.03 & 97.23 & 97.23 & 23.07 & 57.86 & 29.51 & 17.43 & 23.73 & 8.95 & 10.93 & 11.33 \\
\hline 25 or more & 95.19 & 93.22 & 92.79 & 26.06 & 53.09 & 31.37 & 13.02 & 19.46 & 9.23 & 7.85 & 6.61 \\
\hline
\end{tabular}

For notes, see end of table.

of transaction and trust and pension services, which in turn were probably related to firm size and industrial classification.

\section{Loans from Owners, Credit Cards, and Trade Credit}

In addition to using credit lines, loans, and leases, many small businesses obtain financing by borrowing from the firm's owners (owner loans), borrowing via credit cards, or borrowing from suppliers of goods and services (trade credit).

These alternative forms of credit are different from credit lines, loans, and leases in a number of ways. For example, owner loans are not arm's-length transactions, as are institutional loans, because the lender owns some portion of the borrowing firm. The interest rates charged for credit card credit often exceed the interest rates for other types of loans; moreover, 
4.-Continued

A.-Continued

\begin{tabular}{|c|c|c|c|c|c|c|c|c|c|c|c|}
\hline \multirow{2}{*}{ Category } & \multirow{2}{*}{$\begin{array}{c}\text { Any } \\
\text { service }^{1}\end{array}$} & \multicolumn{3}{|c|}{ Liquid asset accounts ${ }^{2}$} & \multicolumn{7}{|c|}{ Credit lines, loans, and capital leases } \\
\hline & & Any & Checking & Savings & Any & $\begin{array}{l}\text { Credit } \\
\text { line }\end{array}$ & Mortgage & Vehicle & $\begin{array}{c}\text { Equip- } \\
\text { ment }\end{array}$ & $\begin{array}{c}\text { Capital } \\
\text { lease }\end{array}$ & Other $^{3}$ \\
\hline \multicolumn{12}{|l|}{ Census region of main office } \\
\hline Northeast $\ldots \ldots \ldots \ldots \ldots$ & 95.81 & 92.85 & 92.22 & 20.36 & 52.57 & 26.10 & 12.90 & 18.21 & 8.39 & 10.99 & 10.42 \\
\hline New England & 94.67 & 92.95 & 92.11 & 23.59 & 54.33 & 22.14 & 12.33 & 20.97 & 7.70 & 11.88 & 12.58 \\
\hline Middle Atlantic & 96.24 & 92.82 & 92.26 & 19.13 & 51.90 & 27.60 & 13.12 & 17.16 & 8.65 & 10.66 & 9.60 \\
\hline Midwest & 96.48 & 95.04 & 94.64 & 23.47 & 59.19 & 29.19 & 15.48 & 21.74 & 11.52 & 9.45 & 10.70 \\
\hline East North Central & 96.54 & 95.58 & 94.98 & 22.88 & 57.45 & 28.15 & 14.53 & 22.22 & 10.99 & 10.99 & 10.74 \\
\hline West North Central & 96.36 & 93.96 & 93.96 & 24.66 & 62.70 & 31.29 & 17.38 & 20.77 & 12.58 & 6.37 & 10.62 \\
\hline South & 96.05 & 94.24 & 94.02 & 16.10 & 54.56 & 28.82 & 12.50 & 21.66 & 10.59 & 10.58 & 8.65 \\
\hline South Atlantic & 96.43 & 94.12 & 94.03 & 14.26 & 53.90 & 29.49 & 11.71 & 21.69 & 10.36 & 10.81 & 9.13 \\
\hline East South Central & 96.51 & 95.54 & 95.54 & 16.69 & 61.63 & 34.63 & 18.09 & 19.35 & 15.00 & 16.31 & 7.75 \\
\hline West South Central & 95.18 & 93.74 & 93.19 & 18.78 & 51.89 & 24.64 & 10.84 & 22.83 & 8.61 & 7.17 & 8.35 \\
\hline West. & 96.37 & 95.29 & 94.88 & 29.98 & 54.16 & 26.27 & 12.75 & 19.86 & 9.85 & 11.25 & 10.47 \\
\hline Mountain & 97.25 & 96.82 & 96.82 & 22.42 & 55.43 & 22.44 & 17.90 & 24.84 & 11.59 & 14.44 & 15.80 \\
\hline Pacific & 96.08 & 94.79 & 94.24 & 32.50 & 53.74 & 27.54 & 11.04 & 18.21 & 9.27 & 10.19 & 8.70 \\
\hline \multicolumn{12}{|l|}{ Urbanization at main office } \\
\hline Urban ....... & 96.45 & 94.76 & 94.34 & 22.30 & 54.00 & 27.81 & 11.16 & 20.41 & 9.57 & 10.97 & 8.97 \\
\hline Rural & 95.12 & 93.13 & 92.86 & 21.82 & 59.42 & 27.28 & 21.76 & 21.09 & 12.61 & 9.07 & 13.67 \\
\hline \multicolumn{12}{|l|}{ Number of offices } \\
\hline One & 95.68 & 93.75 & 93.37 & 21.10 & 52.74 & 25.43 & 12.65 & 19.74 & 9.09 & 9.78 & 9.28 \\
\hline Two . & 100.00 & 99.37 & 98.77 & 30.89 & 67.60 & 41.08 & 16.42 & 24.23 & 19.22 & 14.79 & 12.17 \\
\hline Three or more & 99.13 & 99.13 & 99.13 & 28.76 & 81.61 & 51.22 & 21.75 & 30.36 & 15.30 & 19.20 & 20.26 \\
\hline \multicolumn{12}{|l|}{ Sales area } \\
\hline $\begin{array}{l}\text { Primarily within U.S. } \\
\text { International or global }\end{array}$ & $\begin{array}{l}96.10 \\
97.81\end{array}$ & $\begin{array}{l}94.42 \\
94.60\end{array}$ & $\begin{array}{l}94.01 \\
94.60\end{array}$ & $\begin{array}{l}22.19 \\
22.88\end{array}$ & $\begin{array}{l}55.13 \\
53.46\end{array}$ & $\begin{array}{l}27.29 \\
36.65\end{array}$ & $\begin{array}{r}13.60 \\
6.92\end{array}$ & $\begin{array}{l}20.66 \\
17.09\end{array}$ & $\begin{array}{r}10.30 \\
7.29\end{array}$ & $\begin{array}{l}10.45 \\
12.67\end{array}$ & $\begin{array}{r}9.90 \\
10.04\end{array}$ \\
\hline \multicolumn{12}{|l|}{ Owners' participation } \\
\hline Owner management & 95.93 & 94.10 & 93.68 & 22.16 & 53.75 & 26.87 & 12.72 & 19.90 & 9.91 & 10.24 & 9.79 \\
\hline Hired management. & 99.16 & 98.40 & 98.40 & 22.74 & 70.60 & 37.78 & 20.02 & 27.81 & 13.71 & 14.12 & 11.59 \\
\hline \multicolumn{12}{|l|}{ Race, ethnicity, and sex } \\
\hline Nonwhite or Hispanic & 93.86 & 92.02 & 91.61 & 16.83 & 49.45 & 20.43 & 12.67 & 16.83 & 7.52 & 10.48 & 9.23 \\
\hline Non-Hispanic white & 96.56 & 94.86 & 94.48 & 23.14 & 56.11 & 28.96 & 13.36 & 21.25 & 10.69 & 10.60 & 10.02 \\
\hline White & 96.37 & 94.67 & 94.31 & 22.95 & 55.92 & 28.49 & 13.34 & 20.99 & 10.71 & 10.52 & 9.93 \\
\hline Blac & 91.33 & 88.39 & 87.24 & 13.22 & 48.24 & 18.64 & 11. & 14. & 6.49 & 13.77 & 11.45 \\
\hline Asian or Pacific Islander & 97.50 & 96.20 & 95.92 & 17.90 & 46.41 & 22.54 & 11.84 & 16.35 & 5.01 & 8.39 & 9.12 \\
\hline American Indian or Alaska Native & 92.67 & 92.67 & 92.67 & $10.71 *$ & $51.04 *$ & $16.83 *$ & $18.89^{*}$ & $32.78^{*}$ & $4.31 *$ & $11.89 *$ & $3.98^{*}$ \\
\hline Hispanic & 92.95 & 91.33 & 91.33 & 19.58 & 52.74 & 20.98 & 13.53 & 16.30 & 10.31 & 8.92 & 8.82 \\
\hline Non-Hispanic & 96.36 & 94.64 & 94.23 & 22.37 & 55.18 & 28.02 & 13.26 & 20.82 & 10.20 & 10.66 & 9.95 \\
\hline Femal & 91.85 & 90.32 & 89.92 & 23.57 & 46.13 & 18.42 & 12.76 & 13.56 & 6.41 & 8.07 & 9.72 \\
\hline Male & 97. & 95. & 95 & 21. & 57.39 & 30.33 & 12.94 & 22. & 11.40 & 11.43 & 9.84 \\
\hline Ownership equally divided by sex & 98.34 & 98.02 & 98.02 & 23.15 & 68.42 & 38.40 & 22.63 & 25.90 & 10.37 & 11.16 & 12.99 \\
\hline
\end{tabular}

credit cards, unlike typical loans, provide a convenient means of paying bills and tracking expenses. Trade credit is generally used in connection with the purchase of goods and services from a specific supplier, whereas funds from credit lines, loans, and leases are often available for general purposes and are not restricted to purchases from a single supplier. Also, when outstanding trade credit balances are not repaid in a relatively short period, the finance charges generally exceed those on other loans.

\section{Loans from Owners}

Of the small businesses that could have received loans from owners (that is, those that were organized as corporations or partnerships), 28 percent had such loans in 1998, a slightly smaller percentage than in 1993.

Because they generally have fewer credit options, smaller firms might seem more likely than larger firms to borrow from their owners. This was not the case in 1998. The incidence of owner loans did not generally vary with firm size. For every size group except firms with fewer than two employees, sales of less than $\$ 50,000$, or assets of less than $\$ 25,000$, more than 25 percent of firms had owner loans at year-end 1998. For the smallest firms (by number of employees), fewer than 18 percent had owner loans. The information gathered by the survey regarding size, capitalization, equity injections, and owner loans will enable researchers to examine why the smallest firms had the lowest incidence of this type of loan. 
4. Percentage of small businesses using selected financial services, by selected category of firm, 1998_Continued B. Financial management services

\begin{tabular}{|c|c|c|c|c|c|c|c|c|c|c|}
\hline \multirow{3}{*}{ Category } & \multicolumn{6}{|c|}{ Financial management services 5} & \multicolumn{4}{|c|}{ Мемо: Other credit } \\
\hline & \multirow{2}{*}{ Any } & \multirow{2}{*}{$\begin{array}{l}\text { Trans- } \\
\text { action }\end{array}$} & \multirow{2}{*}{$\begin{array}{c}\text { Cash } \\
\text { manage- } \\
\text { ment }\end{array}$} & \multirow{2}{*}{$\begin{array}{l}\text { Credit- } \\
\text { related }\end{array}$} & \multirow{2}{*}{ Brokerage } & \multirow{2}{*}{$\begin{array}{l}\text { Trust } \\
\text { and } \\
\text { pension }\end{array}$} & \multirow{2}{*}{$\begin{array}{l}\text { Loan } \\
\text { from } \\
\text { owner }^{6}\end{array}$} & \multicolumn{2}{|c|}{ Credit card } & \multirow{2}{*}{$\begin{array}{l}\text { Trade } \\
\text { credit }\end{array}$} \\
\hline & & & & & & & & Personal & Business & \\
\hline All firms, 1998 . & 49.81 & 41.07 & 5.21 & 3.09 & 4.34 & 12.62 & 28.12 & 45.18 & 33.31 & 60.33 \\
\hline All firms, 1993 . & 36.54 & 24.16 & 5.13 & 4.62 & 4.37 & 10.52 & 30.91 & 40.72 & 28.83 & 63.81 \\
\hline \multicolumn{11}{|l|}{ Number of employees ${ }^{4}$} \\
\hline $0-1 \ldots \ldots \ldots$ & 34.49 & 28.07 & $1.57 *$ & $1.42 *$ & 2.67 & 5.60 & 17.49 & 44.91 & 19.19 & 42.69 \\
\hline $2-4$. & 43.81 & 35.73 & 2.75 & 1.45 & 3.21 & 9.01 & 26.25 & 46.75 & 28.46 & 56.86 \\
\hline $5-9$. & 60.54 & 53.18 & 4.00 & 3.66 & 4.90 & 12.49 & 27.47 & 44.00 & 41.93 & 71.14 \\
\hline $10-19$ & 68.69 & 54.29 & 11.94 & 7.93 & 8.63 & 24.78 & 34.24 & 50.38 & 51.39 & 77.90 \\
\hline $20-49$ & 73.98 & 58.99 & 16.61 & 7.23 & 8.94 & 32.81 & 33.69 & 39.51 & 55.61 & 80.67 \\
\hline $50-99$ & 76.83 & 56.79 & 26.95 & 13.21 & 8.80 & 45.08 & 36.02 & 30.29 & 56.52 & 80.67 \\
\hline $100-499$. & 84.75 & 70.21 & 50.83 & 15.37 & 7.95 & 50.51 & 28.76 & 23.00 & 59.67 & 83.37 \\
\hline \multicolumn{11}{|l|}{$\begin{array}{l}\text { Fiscal year sales } \\
\text { (thousands of dollars) }\end{array}$} \\
\hline Less than $25 \ldots \ldots \ldots$. & 29.31 & 25.71 & $2.42 *$ & $.95 *$ & $1.11^{*}$ & $1.81^{*}$ & 21.36 & 41.10 & 11.14 & 30.34 \\
\hline $25-49 \ldots$ & 36.67 & 31.24 & $.95^{*}$ & $.72 *$ & $2.84 *$ & 5.57 & 17.77 & $45.71 *$ & 20.75 & 46.78 \\
\hline $50-99$ & 37.64 & 32.24 & $.95^{*}$ & $.91 *$ & $1.21 *$ & 6.13 & 26.19 & 47.83 & 27.11 & 54.30 \\
\hline $100-249$ & 49.67 & 39.90 & $2.23^{*}$ & $1.22 *$ & 4.41 & 10.81 & 29.12 & 51.84 & 31.90 & 63.01 \\
\hline $250-499$ & 58.64 & 46.64 & 5.04 & 4.57 & 5.16 & 15.18 & 30.08 & 47.59 & 43.06 & 75.85 \\
\hline 500-999 & 63.58 & 59.04 & 5.39 & $4.98^{*}$ & 4.62 & 12.82 & 31.86 & 41.50 & 44.04 & 77.27 \\
\hline $1,000-2,499$. & 71.11 & 51.88 & 12.63 & 6.36 & 11.19 & 27.49 & 26.82 & 45.37 & 54.45 & 80.15 \\
\hline $2,500-4,999$. & 78.64 & 63.69 & 18.42 & 6.19 & 9.69 & 37.70 & 25.74 & 33.21 & 62.68 & 79.86 \\
\hline $5,000-9,999 \ldots$ & 83.30 & 64.74 & 29.95 & 14.21 & 11.74 & 45.43 & 34.98 & 24.79 & 67.66 & 72.10 \\
\hline 10,000 or more $\ldots$ & 89.97 & 67.33 & 45.77 & 23.83 & 12.23 & 62.83 & 29.26 & 22.39 & 62.09 & 76.58 \\
\hline \multicolumn{11}{|l|}{$\begin{array}{l}\text { End-of-year assets } \\
\text { (thousands of dollars) }\end{array}$} \\
\hline Less than $25 \ldots \ldots \ldots$ & 33.96 & 29.33 & $1.31^{*}$ & $.69 *$ & $1.33^{*}$ & 5.00 & 20.55 & 45.52 & 21.35 & 43.22 \\
\hline $25-49 \ldots$ & 45.40 & 36.85 & $.98^{*}$ & $.46^{*}$ & $4.00^{*}$ & 9.08 & 26.00 & 49.80 & 29.22 & 59.78 \\
\hline 50-99. & 52.66 & 43.07 & 3.65 & $2.75^{*}$ & 4.04 & 11.98 & 33.22 & 46.71 & 33.85 & 67.46 \\
\hline $100-249$ & 58.29 & 49.52 & 5.96 & 3.96 & 5.05 & 14.55 & 31.08 & 48.10 & 36.54 & 70.57 \\
\hline $250-499$ & 64.83 & 53.17 & 6.75 & $2.83^{*}$ & 5.74 & 14.75 & 29.37 & 41.78 & 49.33 & 73.82 \\
\hline $500-999$ & 64.31 & 49.92 & 7.69 & 6.64 & 9.75 & 23.13 & 30.03 & 43.95 & 42.97 & 75.30 \\
\hline $1,000-2,499$ & 74.13 & 56.43 & 16.89 & 11.88 & 11.23 & 34.67 & 32.35 & 35.25 & 57.48 & 78.88 \\
\hline $2,500-4,999$ & 85.79 & 69.11 & 37.03 & 15.40 & 13.69 & 42.24 & 31.72 & 25.38 & 65.31 & 80.00 \\
\hline 5,000 or more & 87.93 & 62.25 & 52.27 & 17.27 & 14.53 & 59.16 & 27.30 & 26.53 & 68.11 & 80.59 \\
\hline Organizational form & & & & & & & & & & \\
\hline Proprietorship ..... & 39.78 & 33.24 & 1.94 & 1.48 & 2.78 & 7.63 & & 49.04 & 21.63 & 50.85 \\
\hline Partnership ... & 46.44 & 43.02 & 3.83 & 5.78 & $2.90^{*}$ & 8.90 & 13.10 & 36.92 & 28.45 & 57.82 \\
\hline S corporation . & 59.93 & 48.89 & 9.31 & 4.47 & 5.73 & 15.68 & 30.45 & 43.24 & 46.55 & 71.74 \\
\hline C corporation & 63.79 & 50.46 & 8.89 & 4.48 & 7.03 & 22.69 & 30.57 & 40.79 & 48.12 & 71.08 \\
\hline Standard industrial classification & & & & & & & & & & \\
\hline Construction and mining (10-19) & 35.71 & 27.49 & 6.42 & 5.39 & 5.40 & 8.36 & 27.61 & 39.97 & 33.35 & 77.29 \\
\hline Primary manufacturing (20-29). & 52.83 & 44.70 & 6.90 & 5.77 & $4.20 *$ & 11.96 & 45.49 & 48.91 & 43.18 & 73.23 \\
\hline Other manufacturing $(30-39) \ldots$ & 53.83 & 42.92 & 8.39 & 8.43 & $6.36^{*}$ & 19.23 & 34.53 & 45.89 & 36.00 & 78.19 \\
\hline Transportation $(40-49) \ldots \ldots$ & 50.14 & 43.90 & 5.04 & $3.26^{*}$ & $3.57^{*}$ & 8.42 & 25.74 & 44.10 & 45.39 & 44.15 \\
\hline Wholesale trade (50-51) & 58.53 & 46.60 & 6.01 & 10.42 & 4.13 & 18.76 & 29.66 & 45.14 & 43.56 & 68.46 \\
\hline Retail trade (52-59) ..... & 57.92 & 55.63 & 3.65 & 1.69 & 2.15 & 5.63 & 28.36 & 40.46 & 29.15 & 63.64 \\
\hline Insurance agents and & & & & & & & & & & \\
\hline real estate $(60-69)$ & 38.45 & 26.03 & 7.93 & $2.56^{*}$ & $3.23^{*}$ & 11.32 & 24.13 & 39.68 & 32.68 & 34.62 \\
\hline Business services (70-79) & 47.19 & 40.75 & 4.25 & 1.45 & 3.50 & 9.29 & 26.91 & 46.01 & 28.25 & 59.14 \\
\hline Professional services $(80-89)$. & 53.07 & 36.64 & 4.97 & $.68^{*}$ & 7.19 & 24.54 & 24.76 & 53.39 & 35.40 & 49.57 \\
\hline Years under current ownership & & & & & & & & & & \\
\hline $0-4 \ldots \ldots \ldots \ldots \ldots \ldots$ & 46.59 & 40.22 & 4.13 & 2.71 & 2.17 & 5.76 & 31.66 & 45.64 & 28.14 & 54.11 \\
\hline $5-9$ & 48.75 & 40.71 & 4.27 & 2.37 & 2.92 & 11.92 & 31.64 & 47.75 & 37.79 & 59.74 \\
\hline $10-14$. & 53.22 & 44.02 & 6.06 & 3.03 & 4.62 & 14.17 & 23.54 & 46.30 & 33.09 & 62.04 \\
\hline $15-19$. & 51.42 & 40.79 & 5.67 & 3.99 & 6.95 & 18.44 & 29.47 & 41.86 & 36.52 & 63.94 \\
\hline $20-24$. & 52.05 & 43.90 & 6.24 & 2.60 & 4.72 & 14.40 & 22.44 & 45.07 & 33.65 & 67.56 \\
\hline 25 or more & 49.03 & 37.20 & 6.30 & 4.41 & 7.14 & 16.27 & 25.40 & 41.52 & 31.15 & 60.91 \\
\hline
\end{tabular}

\section{Credit Cards}

Small businesses were somewhat more likely to use credit cards in 1998 compared with 1993. The percentage using personal credit cards for business purposes increased from 41 percent to 45 percent, and the percentage using business credit cards increased from 29 percent to 33 percent.
Credit cards are a convenient means of making payments and tracking expenses. Anecdotal evidence suggests that many smaller and newer businesses also use credit cards as a source of credit, even though it is likely to be more costly than other forms of credit. Lenders sometimes ration credit to high-risk firms. Thus, firms just starting out and those having little credit history may be perceived as high risk and may 
4.-Continued

B.-Continued

\begin{tabular}{|c|c|c|c|c|c|c|c|c|c|c|}
\hline \multirow{3}{*}{ Category } & \multicolumn{6}{|c|}{ Financial management services 5} & \multicolumn{4}{|c|}{ Мемо: Other credit } \\
\hline & \multirow{2}{*}{ Any } & \multirow{2}{*}{$\begin{array}{l}\text { Trans- } \\
\text { action }\end{array}$} & \multirow{2}{*}{$\underset{\text { manage- }}{\text { Cash }}$} & \multirow{2}{*}{$\begin{array}{l}\text { Credit- } \\
\text { related }\end{array}$} & \multirow{2}{*}{ Brokerage } & \multirow{2}{*}{$\begin{array}{l}\text { Trust } \\
\text { and } \\
\text { pension }\end{array}$} & \multirow{2}{*}{$\begin{array}{l}\text { Loan } \\
\text { from } \\
\text { owner }{ }^{6}\end{array}$} & \multicolumn{2}{|c|}{ Credit card } & \multirow{2}{*}{$\begin{array}{l}\text { Trade } \\
\text { credit }\end{array}$} \\
\hline & & & & & & & & Personal & Business & \\
\hline \multicolumn{11}{|l|}{ Census region of main office } \\
\hline Northeast $\ldots \ldots \ldots \ldots \ldots$ & 48.22 & 36.52 & 3.92 & 2.21 & 5.77 & 14.89 & 28.12 & 48.87 & 33.51 & 60.41 \\
\hline New England & 53.59 & 42.04 & 4.43 & $2.36^{*}$ & 7.86 & 13.57 & 31.90 & 50.65 & 40.82 & 63.33 \\
\hline Middle Ätlantic & 46.18 & 34.42 & 3.73 & 2.16 & 4.98 & 15.39 & 26.77 & 48.19 & 30.73 & 59.30 \\
\hline Midwest & 52.95 & 42.63 & 6.86 & 3.77 & 4.44 & 16.42 & 28.38 & 42.20 & 30.86 & 64.27 \\
\hline East North Central & 54.38 & 45.10 & 7.07 & 2.63 & 4.40 & 17.01 & 29.80 & 41.04 & 32.57 & 65.82 \\
\hline West North Central & 50.07 & 37.66 & 6.42 & 6.04 & 4.51 & 15.25 & 25.10 & 44.52 & 27.43 & 61.16 \\
\hline South & 48.22 & 40.56 & 5.86 & 3.59 & 3.93 & 10.38 & 25.73 & 41.15 & 34.36 & 58.77 \\
\hline South Atlantic & 50.82 & 41.61 & 6.28 & 3.60 & 4.87 & 10.81 & 28.32 & 42.10 & 35.89 & 60.13 \\
\hline East South Central & 48.32 & 38.78 & 6.13 & $5.97 *$ & $3.83^{*}$ & 11.23 & 22.54 & 41.95 & 34.29 & 65.81 \\
\hline West South Central & 43.93 & 39.79 & 5.05 & 2.30 & $2.44^{*}$ & 9.24 & 22.12 & 39.18 & 31.90 & 52.82 \\
\hline West. & 50.33 & 43.64 & 3.96 & 2.53 & 3.73 & 10.66 & 31.32 & 49.95 & 33.87 & 58.97 \\
\hline Mountain & 50.31 & 45.03 & 5.10 & $3.21 *$ & $1.87 *$ & 8.99 & 30.55 & 52.05 & 34.77 & 61.68 \\
\hline Pacific ... & 50.34 & 43.18 & 3.58 & 2.31 & 4.35 & 11.21 & 31.67 & 49.26 & 33.57 & 58.06 \\
\hline \multicolumn{11}{|l|}{ Urbanization at main office } \\
\hline Urban ... & 50.80 & 41.81 & 5.41 & 2.76 & 4.64 & 13.49 & 28.58 & 46.00 & 34.05 & 59.81 \\
\hline Rural & 45.89 & 38.11 & 4.40 & 4.39 & 3.12 & 9.20 & 25.74 & 41.90 & 30.35 & 62.39 \\
\hline \multicolumn{11}{|l|}{ Number of offices } \\
\hline One ............. & 47.34 & 39.08 & 4.17 & 2.45 & 3.87 & 11.62 & 27.61 & 45.20 & 31.35 & 58.60 \\
\hline Two ........... & 67.01 & 53.96 & 9.66 & 8.14 & 7.68 & 19.17 & 31.20 & 45.58 & 45.70 & 72.60 \\
\hline Three or more & 70.10 & 59.67 & 19.83 & 6.69 & 7.78 & 21.83 & 28.28 & 44.71 & 51.53 & 73.75 \\
\hline \multicolumn{11}{|l|}{ Sales area } \\
\hline Primarily within U.S. & 49.15 & 40.30 & 5.13 & 2.74 & 4.33 & 12.38 & 28.39 & 44.82 & 32.53 & 60.04 \\
\hline International or global & 64.24 & 57.58 & 6.84 & 10.36 & 4.49 & 17.95 & 22.70 & 53.32 & 49.89 & 67.33 \\
\hline \multicolumn{11}{|l|}{ Owners' participation } \\
\hline $\begin{array}{l}\text { Owner management } \\
\text { Hired management .. }\end{array}$ & $\begin{array}{l}48.59 \\
64.41\end{array}$ & $\begin{array}{l}40.17 \\
51.98\end{array}$ & $\begin{array}{r}4.79 \\
10.47\end{array}$ & $\begin{array}{l}3.00 \\
4.22\end{array}$ & $\begin{array}{l}4.36 \\
4.09\end{array}$ & $\begin{array}{l}11.72 \\
23.20\end{array}$ & $\begin{array}{l}28.02 \\
28.74\end{array}$ & $\begin{array}{l}46.03 \\
35.05\end{array}$ & $\begin{array}{l}32.92 \\
37.96\end{array}$ & $\begin{array}{l}59.45 \\
71.05\end{array}$ \\
\hline \multicolumn{11}{|l|}{ Race, ethnicity, and sex } \\
\hline $\begin{array}{l}\text { of majority owners } \\
\text { Nonwhite or Hispanic }\end{array}$ & 46.84 & 41.04 & 2.75 & 3.07 & 254 & 865 & 2764 & 45. & 2820 & 50.98 \\
\hline Non-Hispanic white & 50.30 & 41.04 & 5.66 & 3.10 & 4.62 & 13.38 & 28.24 & 45.16 & 34.21 & 62.16 \\
\hline White & 49.41 & 40.36 & 5.54 & 3.08 & 4.49 & 12.97 & 28.02 & 44.85 & 33.97 & 61.19 \\
\hline Black & 42.23 & 36.70 & $2.01 *$ & $1.86^{*}$ & $1.92 *$ & 8.75 & 28.05 & 44.05 & 28.78 & 46.20 \\
\hline Asian or Pacific Islander & 67.92 & 62.83 & $2.86^{*}$ & $4.03 *$ & 2.83 & 10.33 & 34.22 & 52.81 & 26.94 & 56.83 \\
\hline American Indian or Alaska Native & $37.86^{*}$ & $25.97 *$ & $.32 *$ & $6.11 *$ & $5.78 *$ & $15.16^{*}$ & 10.84 & $45.19^{*}$ & 19.97* & $75.93 *$ \\
\hline Hispanic & 35.66 & 29.54 & $3.40 *$ & $2.60 *$ & $2.15^{*}$ & 6.66 & 22.80 & 41.75 & 28.95 & 46.37 \\
\hline Non-Hispanic & 50.68 & 41.75 & 5.33 & 3.12 & 4.48 & 13.02 & 28.46 & 45.39 & 33.57 & 61.24 \\
\hline Female & 46.98 & 39.91 & 3.00 & 1.64 & 4.60 & 9.75 & 30.39 & 46.71 & 28.21 & 51.81 \\
\hline Male & 50.37 & 41.17 & 5.67 & 3.52 & 4.38 & 13.68 & 27.41 & 44.77 & 34.64 & 63.07 \\
\hline Ownership equally divided by sex & 55.88 & 44.91 & 10.58 & $4.04 *$ & $1.96^{*}$ & 10.97 & 28.69 & 42.21 & 41.12 & 61.97 \\
\hline
\end{tabular}

1. Excludes owner loans, credit cards, and trade credit.

5. Transaction services: The provision of paper money and coins, the process-

2. Checking accounts: Accounts with unlimited check-writing privileges, including share draft accounts used for business purposes and owners' personal checking accounts if used primarily for business purposes. Savings accounts: Passbook savings accounts, credit union share accounts, certificates of deposit, other time deposits, and money market accounts if they were limited in either the number or the amount of checks that could be written.

3. Includes any loans that could not be classified as credit lines, capital leases, mortgages used for commercial purposes, motor vehicle loans, or equipment loans (in general, any unsecured term loan).

4. See table 1 , note 1 . ing of credit card receipts, the collection of night deposits, and wire transfers. Cash-management services: The provision of sweep accounts, zero-balance accounts, lockbox services, and other services designed to automatically invest liquid funds in liquid, interest-bearing assets. Credit-related services: The provision of bankers acceptances, letters of credit, sales finance, and factoring. Trust and pension services: The provision of $401(\mathrm{k})$ plans, pension funds, business trusts, and securities safekeeping.

6. Percentage of partnerships and corporations using owner loans (excludes proprietorships)

* Fewer than fifteen firms in this category reported using this service, too small a nunber on which to base a reliable statistic.

therefore rely on credit cards as a substitute for other types of loans.

The descriptive results are not entirely consistent with these a priori expectations. The use of business credit cards in 1998 did increase with firm size, but the use of personal credit cards varied little with size, except that the largest firms (those with more than

fifty employees or with sales or assets greater than $\$ 2.5$ million) were less likely than others to use personal credit cards. ${ }^{21}$ Likewise, credit card use did not vary systematically with firm age. Further

21. The amount charged in a typical month and the amount repaid in the same month were also asked in the survey. 
research is needed to determine the extent to which, and the types of firms for which, credit card balances may be a substitute for other types of credit.

Proprietorships were the most likely to use personal credit cards and the least likely to use business credit cards. Insurance and real estate firms were the least likely to use personal credit cards and, along with firms in business services and retail trade, the least likely to use business credit cards.

\section{Trade Credit}

Trade credit is extended when a supplier provides goods and services at one point in time and collects the charges at a later point. If the bills are not paid promptly, trade credit becomes a form of financing. Businesses use trade credit for both transaction and financing purposes. Trade credit reduces the transactions costs that businesses would incur if they had to make payment at the time of delivery, for example, by making funds available for other uses. However, most trade credit is extended for a very short period (thirty or sixty days) and is always granted in connection with specific purchases. The interest rates charged on overdue balances generally are quite high; 2 percent a month is not uncommon. Thus, it is reasonable to expect that the firms using trade credit for longer-term financing purposes are firms that would have difficulty obtaining credit from other sources.

Trade credit was used by 60 percent of small businesses in 1998, an incidence of use that exceeds that for all other financial services except checking. In 1993, 64 percent of small businesses used the service. Use generally increased with firm size; except for the smallest firms, more than half the firms in each size category used trade credit in 1998. Black-, Hispanic-, and female-owned firms were less likely than others to use the service; the differences in use between these groups of firms and others were similar to the differences in use between smaller and larger firms.

The use of trade credit was most common among firms in manufacturing, construction, and wholesale and retail trade-industries for which nonlabor costs, such as the costs of equipment and inventory, are large relative to labor costs. Among industries for which labor's share of costs is high, such as business and professional services, trade credit use was somewhat less common, but it was still used by at least half the firms. The firms least likely to use trade credit were those whose principal activity involved insurance and real estate or transportation.
The survey findings seem to suggest that trade credit was used mainly for transactions purposes. However, some firms undoubtedly used it for financing purposes; further research may help to determine the characteristics of these firms.

\section{SUPPLIERS OF FINANCIAL SERVICES USED BY SMALL BUSINESSES}

The suppliers of financial services to small businesses include financial institutions-depository institutions (commercial banks and thrift institutions, including savings associations, savings banks, and credit unions) as well as nondepository institutions (finance, leasing, mortgage, brokerage, and insurance companies) - and nonfinancial sources (such as individuals, family members, other businesses, and government entities). The survey collected information on the sources of checking and saving services; credit lines, loans, and capital leases; and financial management services. ${ }^{22}$

In 1998, depository institutions and nonfinancial sources were used by a slightly smaller share of the small business population, and nondepository financial institutions by a slightly larger share, than in 1993 (table 5). Among depository institutions, commercial bank use was about the same, but thrift use-despite the deregulation of thrift lending to businesses-was somewhat lower, possibly reflecting the decline in the number of thrift institutions nationwide. The decline in the use of thrifts was due to a decline in the use of savings institutions; the use of credit unions increased over the period, from 4 percent to 6 percent of firms.

Among nondepository financial institutions, the use of leasing companies was somewhat less common and the use of finance companies and "other" nondepository financial institutions (including mortgage banking and insurance companies) was somewhat more common relative to 1993 . These changes are consistent with the finding that the percentage of small businesses that had outstanding mortgages increased over the period between surveys.

\section{Depository Financial Institutions}

Depository institutions provided at least one financial service to about 95 percent of small businesses in 1998 (roughly the same percentage of small busi-

22. Information on the sources of trade credit, credit cards, and owner loans was not collected. 
nesses that had a business checking or savings account in 1998). Commercial banks were used by a far larger percentage of firms (89 percent) than were thrift institutions (savings institutions and credit unions) (12 percent). ${ }^{23}$ In general, the percentage of firms using commercial banks increased with firm size; in contrast, the percentage using thrifts generally declined with firm size. Proprietorships, which are generally the smallest firms, were less likely than firms with other organizational forms to use commercial banks but were about twice as likely as corporations to use thrifts.

The use of thrift institutions declined between 1993 and 1998 , from 15 percent to 12 percent of firms. As in 1993, small businesses in New England were more likely to use thrifts than were those in other parts of the country, probably because of the relatively large number of savings banks in New England.

Black-, Hispanic-, and female-owned firms were less likely than non-Hispanic- and white-owned firms to use commercial banks. Black- and female-owned firms were more likely to use thrifts than were whiteand male-owned businesses. Asian-owned firms were the most likely to use commercial banks and the least likely to use thrifts compared with other ownership groups.

\section{Nondepository Financial Institutions}

Nondepository financial institutions were a source of financial services for about one-third of small businesses in 1998, somewhat more than the fraction in 1993. The most commonly used source was finance companies, followed by brokerage companies.

The use of each type of nondepository financial supplier increased with firm size. About 72 percent of small businesses with more than 100 employees used at least one of these sources; about 30 percent used finance companies and brokerage companies. Use of nondepository financial institutions also differed by organizational form and ranged from 24 percent of proprietorships to 47 percent of $\mathrm{C}$ corporations. Proprietorships and partnerships were half as likely as corporations to use brokerage companies.

The use of nondepository financial institutions varied with the race, ethnicity, and sex of a firm's owners. Female- and black-owned firms were the least likely to use these sources. The differences

23. The percentage of firms that obtained financial services from commercial banks might have been larger had the suppliers of credit cards been included in the calculations, as many business and personal credit cards are issued by commercial banks. among groups were greatest in the use of brokerage companies; for example, 11 percent of white-owned businesses used brokerages, compared with 6 percent of black-owned and Hispanic-owned firms. Femaleowned firms were less likely than male-owned firms to use finance companies, brokerages, and leasing companies.

\section{Nonfinancial Suppliers}

About 12 percent of the small businesses used nonfinancial sources for financial services in 1998. About 6 percent used family and individuals and other businesses, and 1 percent used government sources. ${ }^{24}$

The use of nonfinancial sources did not consistently increase with firm size. For example, the percentage of firms using such sources increased with employment for groups of firms with up to forty-nine employees and with 1998 sales of up to $\$ 2,500,000$. For larger firms, the percentage using such sources generally remained at the higher levels.

Individuals and family were used almost exclusively for credit lines, loans, and leases (table 6). It was expected that the use of individuals or family members as a source of financial services would be most important for younger firms. These firms sometimes have difficulty borrowing from financial institutions, in part because financial institutions often require that prospective borrowers provide several years of financial statements with their loan applications. Nonfinancial sources, especially family members or other individuals familiar with prospective borrowers, may be better positioned to evaluate creditworthiness and to monitor the financial condition of younger firms. Alternatively, nonfinancial sources may have lower credit standards than financial institutions. The survey results show that in 1998 the use of family or individuals was most common among firms younger than five years and among those that had been operating for fifteen to nineteen years; it was least common among firms that had been operating for more than twenty-five years. Thus, the expectation regarding firm age and the use of nonfinancial sources is not entirely consistent with the descriptive data from the survey. However, further analysis that statistically controls for factors besides age could lead to a different conclusion.

24. This figure may understate the true role of government in providing financial services to small businesses. Many entities, such as the U.S. Small Business Administration, provide credit guarantees, which ensure repayment of small business loans made by institutional lenders such as commercial banks and thrift institutions. 
5. Percentage of small businesses using selected suppliers of financial services, by selected category of firm, 1998 A. Any supplier, any financial institution, and depository institutions

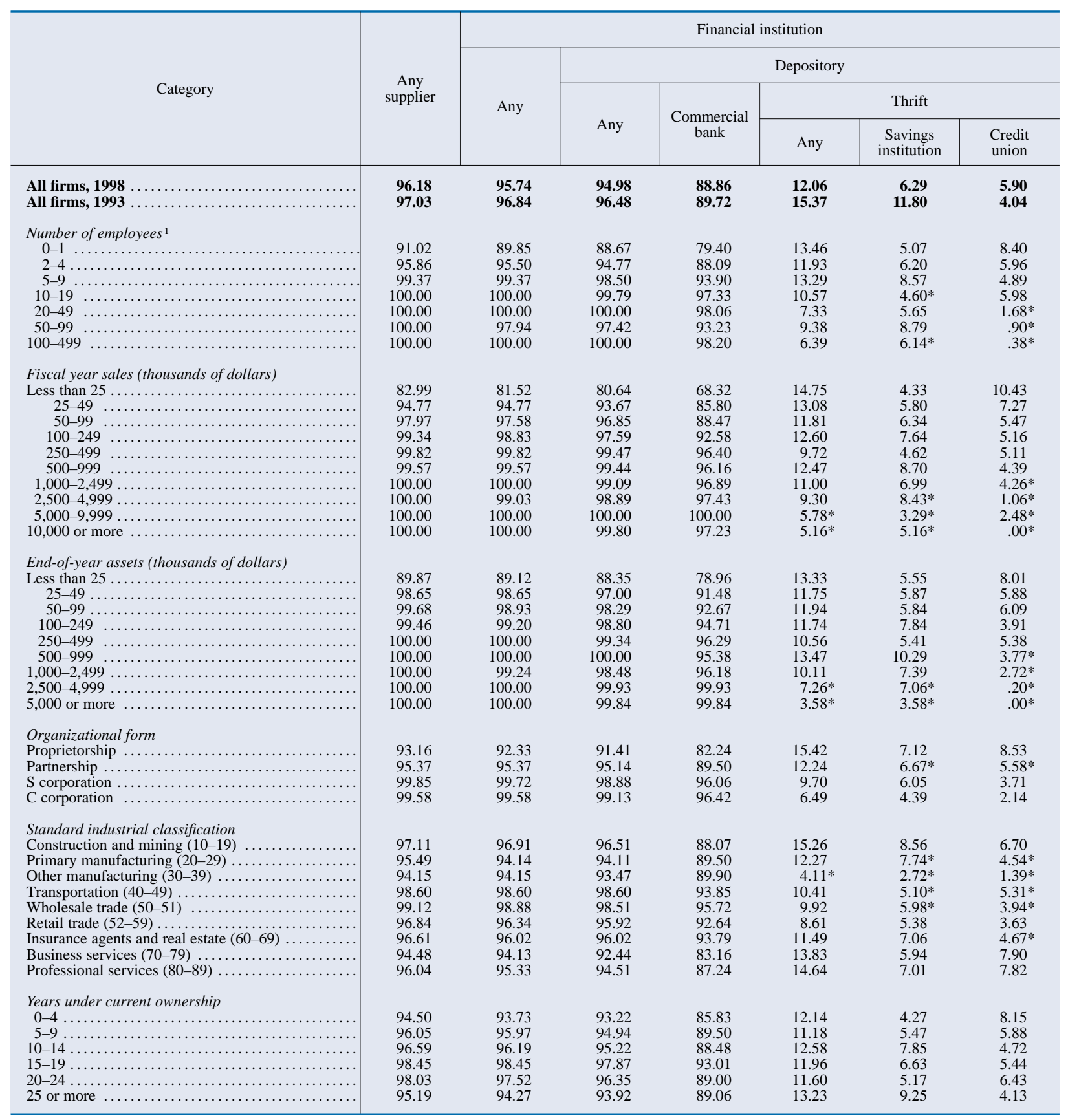

For notes, see end of table.

\section{USE OF FINANCIAL SERVICES SUPPLIERS, BY SERVICE}

The data reviewed thus far have examined separately the use of financial services by firm characteristics and the sources of financial services by firm type. This section reports on the types of financial services provided to small businesses by each type of financial service supplier.

\section{Suppliers of Checking and Savings Services}

As in 1993, commercial banks dominated the provision of checking services to small businesses in 1998 , 


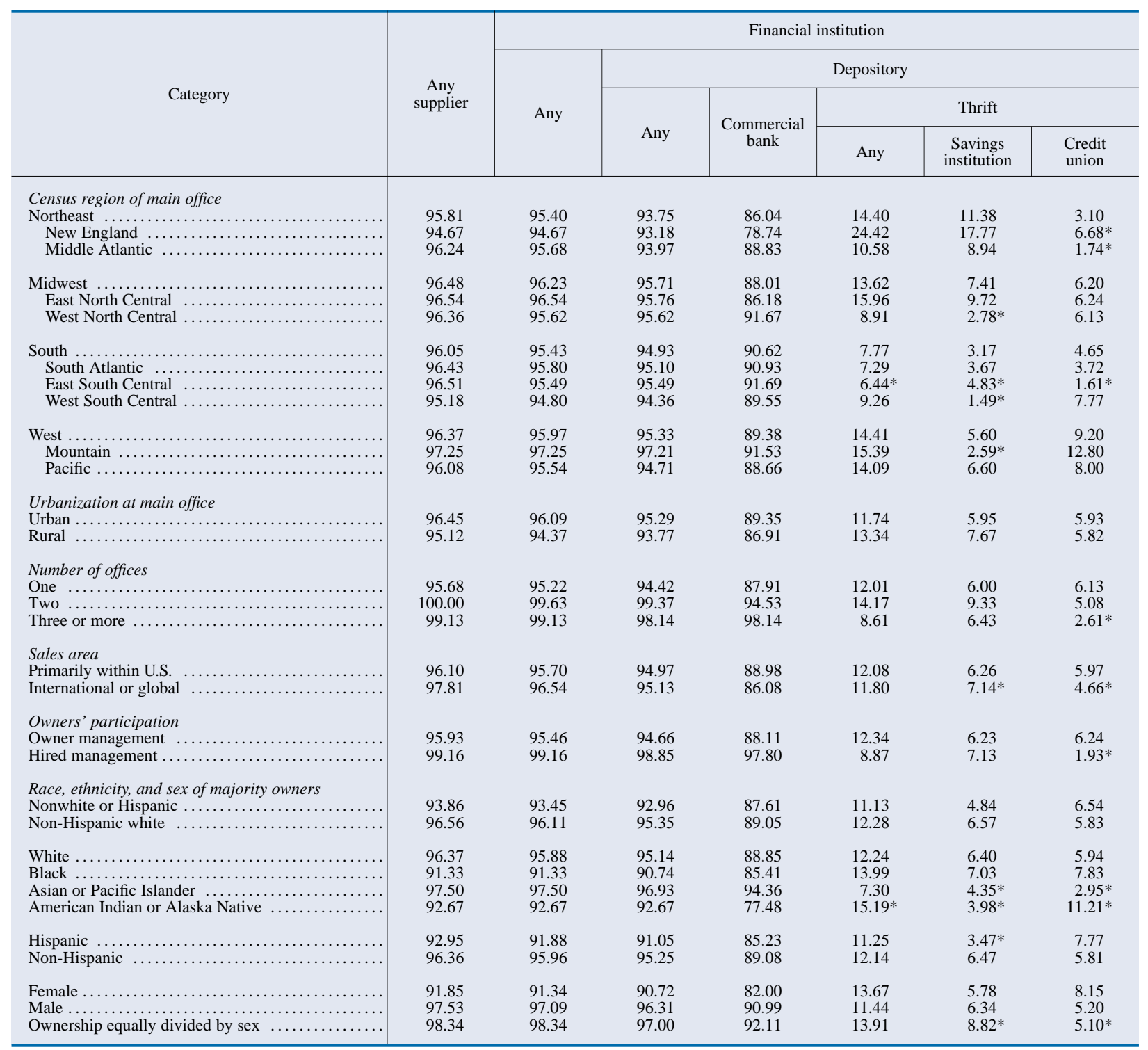

supplying these services to 86 percent of all firms surveyed (table 6). Savings institutions and credit unions were sources for fewer than 5 percent of firms. No other single type of supplier provided more than a trivial share of checking services. Commercial banks were also the dominant supplier of savings services, far outpacing the next most common providers (thrift institutions and brokerage firms).

\section{Suppliers of Lines of Credit, Loans, and Capital Leases}

Commercial banks were also the most common supplier of lines of credit, loans, and capital leases in
1998; about 39 percent of small businesses had a credit line, loan, or capital lease from a commercial bank at the end of 1998 (compared with 41 percent of firms at the end of 1993). Nondepository financial institutions and family and individuals were also important suppliers; in 1998, as in 1993, about 20 percent of firms obtained credit lines from or had outstanding loan or capital lease balances with nondepository financial institutions (specifically, finance companies and leasing companies); 6 percent had loans from family and individuals (compared with 9 percent in 1993). Although suppliers other than commercial banks were important sources of credit, commercial banks were three times more 
5. Percentage of small businesses using selected suppliers of financial services, by selected category of firm, 1998 — Continued B. Nondepository financial institutions and nonfinancial suppliers

\begin{tabular}{|c|c|c|c|c|c|c|c|c|c|}
\hline \multirow[b]{2}{*}{ Category } & \multicolumn{5}{|c|}{ Nondepository financial institution } & \multicolumn{4}{|c|}{ Nonfinancial supplier } \\
\hline & Any & $\begin{array}{l}\text { Finance } \\
\text { company }\end{array}$ & Brokerage & $\begin{array}{l}\text { Leasing } \\
\text { company }\end{array}$ & Other & Any ${ }^{2}$ & $\begin{array}{c}\text { Family } \\
\text { and } \\
\text { individuals }\end{array}$ & $\begin{array}{c}\text { Other } \\
\text { businesses }\end{array}$ & $\begin{array}{c}\text { Govern- } \\
\text { ment }\end{array}$ \\
\hline All firms, 1998 & 32.65 & 14.47 & 10.88 & 7.48 & 7.17 & 12.46 & 6.14 & 5.95 & 1.04 \\
\hline All firms, 1993 & 30.80 & 13.82 & 10.20 & 8.56 & 3.59 & 15.61 & 8.90 & 7.43 & $\begin{array}{r}.04 \\
.64\end{array}$ \\
\hline \multicolumn{10}{|l|}{ Number of employees ${ }^{1}$} \\
\hline $0-1 \ldots \ldots \ldots \ldots \ldots$ & 17.28 & 6.78 & 5.84 & 3.37 & 3.95 & 9.04 & 3.95 & 4.82 & $.45^{*}$ \\
\hline $2-4$. & 28.37 & 13.54 & 8.75 & 4.64 & 5.81 & 10.02 & 5.90 & 4.12 & $.62 *$ \\
\hline $5-9$ & 38.53 & 17.02 & 12.44 & 10.22 & 8.91 & 13.59 & 6.15 & 6.88 & $1.29 *$ \\
\hline $10-19$ & 53.46 & 21.41 & 17.43 & 17.80 & 11.02 & 20.40 & 8.66 & 10.46 & $2.05 *$ \\
\hline $20-49$ & 57.69 & 25.59 & 23.94 & 12.12 & 13.28 & 25.45 & 12.93 & 11.82 & $3.20 *$ \\
\hline $50-99$ & 60.01 & 27.29 & 21.45 & 23.02 & 17.00 & 18.85 & 6.88 & 9.28 & $3.29 *$ \\
\hline $100-499 \ldots$ & 71.66 & 30.38 & 32.58 & 23.42 & 17.32 & 18.50 & 4.63 & 12.87 & $2.75^{*}$ \\
\hline \multicolumn{10}{|l|}{ Fiscal year sales (thousands of dollars) } \\
\hline Less than $25 \ldots \ldots \ldots \ldots \ldots \ldots \ldots \ldots \ldots$ & 11.65 & 4.90 & $2.27 *$ & $1.44 *$ & 3.26 & 9.46 & 5.19 & 3.87 & $.54 *$ \\
\hline $25-49 \ldots$ & 20.55 & 8.41 & $6.23 *$ & $1.93 *$ & 5.40 & 6.21 & $2.92 *$ & $3.03 *$ & $.26^{*}$ \\
\hline $50-99$ & 22.73 & 10.08 & 4.76 & 5.29 & 4.33 & 9.36 & 4.78 & 4.84 & $.51 *$ \\
\hline $100-249$ & 32.48 & 15.81 & 11.33 & 7.41 & 6.13 & 13.36 & 7.52 & 5.57 & $91 *$ \\
\hline $250-499$ & 39.53 & 14.93 & 14.49 & 7.93 & 8.97 & 12.52 & 7.32 & 4.70 & $1.32 *$ \\
\hline $500-999$ & 42.86 & 19.99 & 11.26 & 14.84 & 11.33 & 16.84 & 6.29 & 10.56 & $82 *$ \\
\hline $1,000-2,499$ & 57.28 & 25.47 & 23.14 & 12.77 & 9.82 & 19.68 & 8.35 & 9.86 & $3.34 *$ \\
\hline $2,500-4,999$ & 60.07 & 30.76 & 20.85 & 18.26 & 11.96 & 17.17 & 7.41 & 8.81 & $1.55^{*}$ \\
\hline $5,000-9,999$ & 70.25 & 25.66 & 28.05 & 13.49 & 18.63 & 20.13 & $6.20 *$ & 11.17 & $3.72 *$ \\
\hline 10,000 or more & 70.95 & 30.84 & 41.20 & 17.49 & 19.34 & 15.94 & 4.82 & 10.73 & $1.69^{*}$ \\
\hline \multicolumn{10}{|l|}{ End-of-year assets (thousands of dollars) } \\
\hline 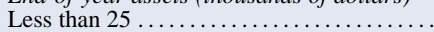 & 17.02 & 7.90 & 4.45 & 3.61 & 4.07 & 7.93 & 4.06 & 3.57 & $.37 *$ \\
\hline $25-49$ & 25.51 & 12.29 & 9.69 & 4.25 & 4.01 & 7.40 & 3.71 & $3.57 *$ & $.10^{*}$ \\
\hline $50-99$ & 36.14 & 16.23 & 11.23 & 7.98 & 7.27 & 12.68 & 6.29 & 6.51 & $.21 *$ \\
\hline $100-249$ & 41.55 & 18.09 & 12.11 & 9.45 & 10.46 & 17.06 & 8.85 & 8.18 & $1.42 *$ \\
\hline $250-499$ & 43.99 & 18.16 & 15.22 & 10.89 & 8.97 & 14.39 & 7.71 & 6.48 & $1.89 *$ \\
\hline $500-999$ & 54.74 & 23.15 & 21.25 & 16.26 & 10.43 & 19.11 & 9.85 & $\begin{array}{l}0.40 \\
7.74\end{array}$ & $2.47 *$ \\
\hline $1,000-2,499$ & 57.01 & 23.82 & 22.76 & 10.48 & 16.00 & 25.80 & 9.87 & 13.90 & $3.47 *$ \\
\hline $2,500-4,999$ & 64.62 & 25.90 & 36.86 & 26.98 & 10.44 & 14.03 & $4.00 *$ & 6.88 & $3.47 *$ \\
\hline 5,000 or more & 68.01 & 30.11 & 29.87 & 16.14 & 17.28 & 27.33 & 5.80 & 20.93 & $2.46^{*}$ \\
\hline \multicolumn{10}{|l|}{ Organizational form } \\
\hline Proprietorship ..... & 23.90 & 10.75 & 7.61 & 3.58 & 5.06 & 10.86 & 5.68 & 5.13 & $.57 *$ \\
\hline Partnership ... & 29.60 & 15.53 & 6.55 & 9.42 & $5.16 *$ & 9.00 & $2.74 *$ & $4.27 *$ & $1.98 *$ \\
\hline S corporation & 39.70 & 16.84 & 13.79 & 11.73 & 7.65 & 13.98 & 6.37 & 7.43 & .93 \\
\hline C corporation & 47.03 & 20.54 & 17.02 & 11.39 & 12.56 & 15.85 & 8.18 & 6.82 & 2.03 \\
\hline \multicolumn{10}{|l|}{ Standard industrial classification } \\
\hline Construction and mining $(10-19)$ & 31.12 & 18.06 & 10.87 & 3.52 & 4.50 & 7.74 & 3.44 & 4.35 & $.92 *$ \\
\hline Primary manufacturing $(20-29)$.. & 31.79 & 12.04 & 6.93 & 13.00 & 6.54 & 18.87 & 7.81 & 12.14 & $1.30^{*}$ \\
\hline Other manufacturing $(30-39)$. & 37.88 & 11.46 & 15.79 & 9.59 & 8.97 & 16.99 & 10.34 & 5.13 & $1.76^{*}$ \\
\hline Transportation $(40-49)$. & 34.83 & 19.38 & 6.90 & 7.55 & 8.65 & 13.77 & $6.17 *$ & $7.61 *$ & $.02 *$ \\
\hline Wholesale trade $(50-51)$ & 42.10 & 19.18 & 13.24 & 9.66 & 10.87 & 13.09 & 7.19 & 4.43 & $1.77 *$ \\
\hline Retail trade $(52-59) \ldots \ldots$ & 28.71 & 13.15 & 5.50 & 4.21 & 11.44 & 14.82 & 5.53 & 8.18 & 1.93 \\
\hline \multicolumn{10}{|l|}{ Insurance agents and } \\
\hline real estate $(60-69)$ & 29.88 & 13.90 & 10.79 & 7.43 & 4.68 & 12.63 & 8.33 & $4.98 *$ & .00 \\
\hline Business services $(70-79)$ & 29.31 & 13.38 & 8.33 & 9.06 & 5.59 & 12.33 & 6.90 & 5.24 & $.74 *$ \\
\hline Professional services $(80-89)$ & 38.24 & 13.77 & 19.38 & 8.87 & 5.50 & 10.41 & 4.94 & 5.31 & $.68^{*}$ \\
\hline \multicolumn{10}{|l|}{ Years under current ownership } \\
\hline $0-4 \ldots \ldots \ldots \ldots \ldots \ldots \ldots$ & 28.33 & 13.72 & 5.78 & 6.64 & 7.70 & 13.55 & 7.84 & 5.33 & $.92 *$ \\
\hline $5-9$ & 33.84 & 14.55 & 9.00 & 10.44 & 6.34 & 10.63 & 6.44 & 3.74 & $.54 *$ \\
\hline $10-14$ & 37.13 & 16.37 & 12.97 & 8.43 & 8.56 & 11.53 & 4.95 & 6.51 & $96^{*}$ \\
\hline $15-19$. & 34.33 & 13.50 & 13.65 & 7.29 & 7.65 & 13.67 & 7.19 & 6.83 & $1.38 *$ \\
\hline $20-24$ & 30.81 & 14.02 & 12.57 & 5.80 & 6.76 & 15.43 & 5.93 & 7.17 & $2.77 *$ \\
\hline 25 or more & 30.81 & 13.67 & 15.81 & 3.61 & 5.65 & 11.51 & 3.42 & 7.99 & $.80^{*}$ \\
\hline
\end{tabular}

likely than finance companies, five times more likely than leasing companies, and about six times more likely than family or individuals to be the source of these services for small businesses in 1998.

Credit lines were supplied almost exclusively by commercial banks: About 25 percent of firms obtained credit lines from commercial banks, compared with about 2 percent for the next most important source, finance companies. Vehicle loans were obtained mainly from commercial banks (11 percent of firms) and finance companies (about 8 percent). Equipment loans were also obtained mainly from these sources, with finance companies used at about half the rate of commercial banks. The only type of credit service that was not provided mainly by commercial banks was capital leases, which were twice as likely to be obtained from leasing companies as from commercial banks or finance companies; however, only about 11 percent of small businesses had a capital lease in 1998. Finally, family and indi- 
5.-Continued

B.-Continued

\begin{tabular}{|c|c|c|c|c|c|c|c|c|c|}
\hline \multirow[b]{2}{*}{ Category } & \multicolumn{5}{|c|}{ Nondepository financial institution } & \multicolumn{4}{|c|}{ Nonfinancial supplier } \\
\hline & Any & $\begin{array}{l}\text { Finance } \\
\text { company }\end{array}$ & Brokerage & $\begin{array}{c}\text { Leasing } \\
\text { company }\end{array}$ & Other & Any ${ }^{2}$ & $\begin{array}{c}\text { Family } \\
\text { and } \\
\text { individuals }\end{array}$ & $\begin{array}{c}\text { Other } \\
\text { businesses }\end{array}$ & $\begin{array}{c}\text { Govern- } \\
\text { ment }\end{array}$ \\
\hline \multicolumn{10}{|l|}{ Census region of main office } \\
\hline Northeast $\ldots \ldots \ldots \ldots \ldots$ & 36.04 & 16.46 & 14.89 & 7.14 & 6.73 & 12.75 & 5.92 & 6.41 & $.68^{*}$ \\
\hline New England & 35.00 & 16.91 & 15.31 & 6.60 & 6.31 & 13.94 & $7.03 *$ & 6.71 & $.03 *$ \\
\hline Middle Atlantic & 36.44 & 16.29 & 14.74 & 7.34 & 6.89 & 12.29 & 5.50 & 6.29 & $.59 *$ \\
\hline Midwest & 30.15 & 11.73 & 11.01 & 6.69 & 7.08 & 12.69 & 6.10 & 6.16 & $1.20 *$ \\
\hline East North Central & 31.51 & 12.21 & 11.31 & 6.82 & 7.63 & 14.21 & 7.61 & 6.59 & $.79 *$ \\
\hline West North Central & 27.41 & 10.76 & 10.41 & 6.44 & 5.97 & 9.65 & $3.08^{*}$ & 5.30 & $2.02 *$ \\
\hline South & 31.16 & 14.59 & 8.27 & 7.95 & 6.85 & 11.70 & 5.18 & 5.90 & .96 \\
\hline South Atlantic & 34.37 & 16.37 & 8.88 & 9.56 & 6.67 & 14.03 & 6.95 & 6.58 & $.63^{*}$ \\
\hline East South Central & 29.49 & 13.80 & 7.91 & 7.71 & 6.31 & 7.29 & $3.97 *$ & $2.49^{*}$ & $1.66^{*}$ \\
\hline West South Central & 26.82 & 12.11 & 7.45 & 5.46 & 7.43 & 10.22 & 2.94 & 6.59 & $1.15^{*}$ \\
\hline West. & 34.13 & 15.17 & 11.12 & 7.79 & 7.96 & 13.02 & 7.50 & 5.54 & 1.26 \\
\hline \multirow{2}{*}{$\begin{array}{l}\text { Mountain } \\
\text { Pacific .... }\end{array}$} & 29.71 & 13.17 & 8.11 & 6.55 & 6.82 & 17.54 & 8.89 & 7.38 & $3.60^{*}$ \\
\hline & 35.60 & 15.83 & 12.12 & 8.20 & 8.33 & 11.51 & $\begin{array}{l}8.89 \\
7.04\end{array}$ & 4.93 & $\begin{array}{l}3.00 * \\
.49 *\end{array}$ \\
\hline \multicolumn{10}{|l|}{ Urbanization at main office } \\
\hline Urban..$\ldots \ldots \ldots \ldots \ldots$ & 34.32 & 15.16 & 11.98 & 8.16 & 7.48 & 12.00 & 5.84 & 6.08 & .79 \\
\hline Rural & 26.01 & 11.75 & 6.49 & 4.77 & 5.93 & 14.33 & 7.34 & 5.46 & 2.05 \\
\hline \multicolumn{10}{|l|}{ Number of offices } \\
\hline One & 30.61 & 13.43 & 10.23 & 6.79 & 6.64 & 11.71 & 5.89 & 5.46 & 1.08 \\
\hline Two ........... & 45.87 & 21.88 & 14.95 & 10.29 & 10.21 & 16.52 & 6.51 & 9.67 & $.47 *$ \\
\hline Three or more & 50.30 & 21.26 & 17.09 & 16.40 & 13.03 & 20.05 & 11.35 & 7.88 & $1.51 *$ \\
\hline \multicolumn{10}{|l|}{ Sales area } \\
\hline Primarily within U.S. & 32.19 & 14.21 & 10.82 & 7.31 & 6.76 & 12.35 & 6.16 & 5.81 & 1.05 \\
\hline International or global & 41.47 & 18.94 & 12.31 & 10.13 & 16.04 & 13.56 & 5.29 & 8.10 & $.87^{*}$ \\
\hline \multicolumn{10}{|l|}{ Owners' participation } \\
\hline Hired management . . & $\begin{array}{l}31.69 \\
43.23\end{array}$ & $\begin{array}{l}14.10 \\
18.19\end{array}$ & $\begin{array}{l}10.57 \\
14.44\end{array}$ & $\begin{array}{r}1.09 \\
11.47\end{array}$ & $\begin{array}{l}6.98 \\
9.26\end{array}$ & $\begin{array}{l}12.31 \\
13.40\end{array}$ & $\begin{array}{l}6.17 \\
5.31\end{array}$ & $\begin{array}{l}5.72 \\
8.36\end{array}$ & $\begin{array}{l}1.07 \\
.71 *\end{array}$ \\
\hline \multicolumn{10}{|l|}{ Race, ethnicity, and sex of majority owners } \\
\hline Nonwhite or Hispanic & 30.91 & 14.17 & 7.09 & 7.56 & 9.00 & 13.47 & 8.05 & 5.01 & $1.08^{*}$ \\
\hline Non-Hispanic white & 32.88 & 14.54 & 11.55 & 7.41 & 6.85 & 12.31 & 5.85 & 6.15 & .99 \\
\hline White & 32.69 & 14.49 & 11.17 & 7.45 & 6.84 & 12.37 & 5.95 & 6.06 & 1.03 \\
\hline Black .................. & 28.74 & 15.03 & 6.02 & 7.89 & 8.18 & 16.57 & 10.32 & 5.81 & $1.29 *$ \\
\hline Asian or Pacific Islander & 32.73 & 12.58 & 9.27 & 6.13 & 13.23 & 12.59 & $7.21 *$ & $5.81 *$ & $.22 *$ \\
\hline American Indian or Alaska Native & $40.50^{*}$ & $22.55^{*}$ & $14.26^{*}$ & $8.67 *$ & $6.37 *$ & $4.31 *$ & $3.98^{*}$ & $.32 *$ & $.32 *$ \\
\hline Hispanic .. & 30.40 & 13.70 & 5.63 & 7.87 & 7.15 & 13.57 & 8.29 & $4.73 *$ & $1.64^{*}$ \\
\hline Non-Hispanic & 32.74 & 14.51 & 11.23 & 7.39 & 7.20 & 12.39 & 6.03 & 6.05 & .96 \\
\hline Female & 29.18 & 12.05 & 9.71 & 6.43 & 7.37 & 12.29 & 6.07 & 5.36 & $1.22 *$ \\
\hline Male ... & 33.55 & 15.06 & 11.43 & 7.54 & 7.07 & 12.56 & 6.06 & 6.26 & 1.01 \\
\hline Ownership equally divided by sex & 36.48 & 18.08 & 8.06 & 12.47 & $7.77 *$ & 9.81 & $6.12 *$ & $4.07 *$ & $.56^{*}$ \\
\hline
\end{tabular}

1. See table 1 , note 1 .

* Fewer than fifteen firms in this category reported using this supplier, too

2. Includes a few sources for which the type could not be determined (fewer small a number on which to base a reliable statistic.

than 1 percent of the sources identified by respondents).

viduals provided "other" loans at about the same rate as did commercial banks.

\section{Suppliers of Financial Management Services}

Commercial banks were the dominant supplier of financial management services, serving about 38 percent of small businesses in 1998. Brokerages, the second most common source of these services, were used by about 10 percent of firms. Brokerages were the leading provider of both brokerage services and trust and pension services, and commercial banks were the leading provider of transaction, cashmanagement, and credit-related services.

\section{SUMMARY}

The 1998 Survey of Small Business Finances provides detailed information on the characteristics of small businesses and on the types and sources of credit and other financial services they use. Although the discussion in this article is based on descriptive statistics, the data suggest interesting behavior patterns and differences in the use of credit by small businesses. (Standard errors for the differences have not been calculated, so it is uncertain whether these differences are statistically significant.)

The 1998 survey is the third in a series of surveys of small businesses sponsored by the Board of Gov- 
6. Percentage of small businesses using selected suppliers of financial services, by selected service, 1998

\begin{tabular}{|c|c|c|c|c|c|c|c|c|c|c|c|c|}
\hline \multirow{4}{*}{ Service } & \multirow{4}{*}{$\begin{array}{c}\text { Any } \\
\text { supplier }\end{array}$} & \multicolumn{11}{|c|}{ Financial institution } \\
\hline & & \multirow{3}{*}{ Any } & \multicolumn{5}{|c|}{ Depository } & \multirow{2}{*}{\multicolumn{5}{|c|}{ Nondepository }} \\
\hline & & & \multirow[b]{2}{*}{ Any } & \multirow{2}{*}{$\begin{array}{c}\text { Commer- } \\
\text { cial } \\
\text { bank }\end{array}$} & \multicolumn{3}{|c|}{ Thrift } & & & & & \\
\hline & & & & & Any & $\begin{array}{c}\text { Savings } \\
\text { insti- } \\
\text { tution }\end{array}$ & $\begin{array}{l}\text { Credit } \\
\text { union }\end{array}$ & Any & $\begin{array}{l}\text { Finance } \\
\text { company }\end{array}$ & $\begin{array}{l}\text { Broker- } \\
\text { age }\end{array}$ & $\begin{array}{l}\text { Leasing } \\
\text { company }\end{array}$ & Other \\
\hline Any & 96.18 & 95.74 & 94.98 & 88.86 & 12.06 & 6.29 & 5.90 & 32.65 & 14.47 & 10.88 & 7.48 & 7.17 \\
\hline Liquid asset account ${ }^{1}$ & 94.43 & 94.12 & 93.58 & 86.67 & 8.89 & 4.66 & 4.26 & 3.18 & .49 & 2.58 & $.00 *$ & $.16^{*}$ \\
\hline Checking....... & 94.04 & 93.73 & 93.19 & 86.30 & 8.06 & 4.28 & 3.80 & 1.31 & $26 *$ & .98 & $.00 *$ & $.07 *$ \\
\hline Savings .. & 22.20 & 21.91 & 20.56 & 17.84 & 3.08 & 1.08 & 1.99 & 2.10 & .28 & 1.73 & $.00^{*}$ & $.10^{*}$ \\
\hline $\begin{array}{c}\text { Credit lines, loans, and } \\
\text { capital leases } \ldots . . .\end{array}$ & 55.09 & 51.36 & 41.96 & 38.88 & 4.87 & 2.45 & 2.45 & 20.11 & 12.62 & .31 & 7.37 & 1.67 \\
\hline Line of credit $\ldots \ldots$ & 27.71 & 27.04 & 25.61 & 24.70 & 1.15 & $\begin{array}{r}2.45 \\
.74\end{array}$ & .41 & 2.21 & 1.64 & $.23 *$ & $.34 *$ & $.14 *$ \\
\hline Mortgage .... & 13.29 & 11.68 & 10.16 & 8.82 & 1.42 & 1.18 & $.24 *$ & 1.85 & .58 & $.00 *$ & $.07 *$ & 1.23 \\
\hline Vehicle .. & 20.55 & 20.11 & 13.16 & 11.30 & 2.07 & .48 & 1.59 & 8.59 & 7.91 & $.04 *$ & .61 & $.07 *$ \\
\hline Equipment ... & 10.18 & 8.89 & 5.91 & 5.36 & .55 & $.28 *$ & $.27 *$ & 3.37 & 2.14 & $.00 *$ & 1.31 & $.00^{*}$ \\
\hline Capital lease & 10.59 & 9.58 & 2.65 & 2.40 & $.25^{*}$ & $.16^{*}$ & $.10^{*}$ & 7.63 & 2.30 & $.05^{*}$ & 5.59 & $.02 *$ \\
\hline Other ${ }^{2} \ldots \ldots$ & 9.92 & 5.02 & 4.45 & 4.22 & $.24 *$ & $.10 *$ & $.13^{*}$ & .69 & .37 & $.04 *$ & $.05 *$ & $.24 *$ \\
\hline Financial management ${ }^{3}$ & 49.81 & 48.10 & 40.25 & 38.15 & 3.00 & 1.51 & 1.52 & 17.29 & 2.90 & 9.74 & .42 & 5.68 \\
\hline Transaction ........... & 41.07 & 39.75 & 37.24 & 35.27 & 2.78 & 1.41 & 1.39 & 5.60 & 1.64 & .49 & $20 *$ & 3.62 \\
\hline Cash-management . & 5.21 & 5.09 & 4.73 & 4.54 & $.31 *$ & $.22 *$ & $.09 *$ & .46 & $.06^{*}$ & .40 & $.00 *$ & $.00 *$ \\
\hline Credit-related ... & 3.09 & 3.02 & 2.47 & 2.39 & $.12 *$ & $.00 *$ & $.11 *$ & .67 & .51 & $.00 *$ & $.14 *$ & $.02 *$ \\
\hline Brokerage ... & 4.34 & 4.18 & .26 & .25 & $.01 *$ & $.00 *$ & $.01 *$ & 4.05 & $.11 *$ & 3.84 & $.05^{*}$ & $.07 *$ \\
\hline Trust and pension. & 12.62 & 11.65 & 2.76 & 2.71 & $.06^{*}$ & $.01 *$ & $.04 *$ & 9.27 & .76 & 6.56 & $.04 *$ & 2.14 \\
\hline
\end{tabular}

For notes, see end of table.

ernors. Straightforward comparisons reveal some remarkable similarities in the findings from the 1998 and 1993 surveys. In particular, commercial banks continued in 1998 to be the dominant source of financial services for small businesses, including checking and savings accounts, loans of all types except capital leases, and all financial management services other than brokerage services and trust and pension services.

Comparisons also reveal some changes over the period between surveys. Minority- and femaleowned firms accounted for a larger proportion of small businesses in 1998. The incidence of vehicle, equipment, and "other" loans declined somewhat over the period, while the incidence of lines of credit and mortgages increased. Some of the differences are undoubtedly due to differences in the economic climate in which small businesses operated during 1993 and 1998.

Explaining the differences and, more fundamentally, understanding the factors that affect small business financing require a rigorous analytical framework that accounts for the financial characteristics of borrowers and the markets in which they operate. Although such analysis is beyond the scope of this article, the final survey data will provide considerable opportunities for more formal and complete analyses.

\section{APPENDIX: SURVEY METHODS}

The 1998 Survey of Small Business Finances, conducted in 1999 and 2000 by the National Opinion Research Center (NORC) for the Board of Governors, covered a nationally representative sample of small businesses. The target population was U.S. domestic for-profit, nonfinancial, nonsubsidiary, nonagricultural, nongovernmental businesses with fewer than 500 employees that were in operation on December 31, 1998. The sample was drawn from the Dun \& Bradstreet Market Identifier file. ${ }^{25}$

The Market Identifier file is broadly representative of all businesses in the United States (though it may underrepresent many of the newest and smallest businesses). It has been estimated that the Dun \& Bradstreet database covers approximately 93 percent of full-time business activity. ${ }^{26}$

The 1998 Statistics of U.S. Businesses from the U.S. Small Business Administration provides a comparison population (http://www.sba.gov/advo/stats/ data.html) for the population obtained from the Dun \& Bradstreet file. These data are compiled by the U.S. Census Bureau and contain virtually the

25. Dun's Marketing Service, Dun \& Bradstreet, Inc.

26. See Bruce Phillips and Bruce Kirchhoff, "Formation, Growth, and Survival: Small Firm Dynamics in the U.S. Economy," Small Business Economics, vol. 1 (1989), pp. 65-74. 
6.-Continued

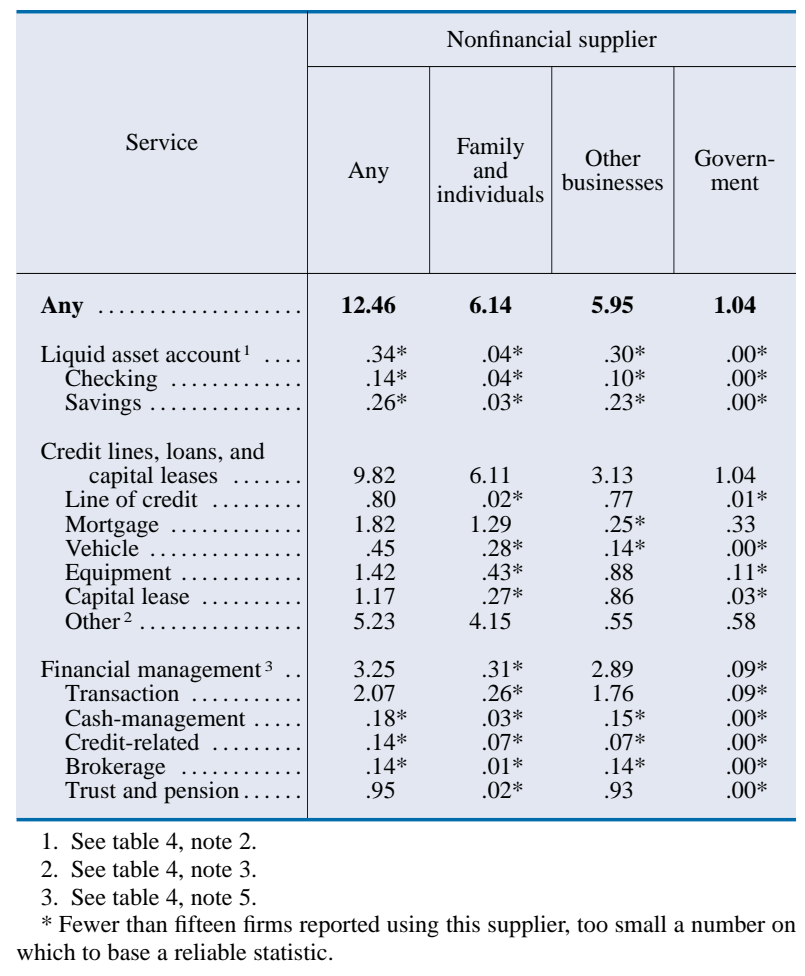

entire universe of private-sector businesses with positive payroll, excluding farms (SIC 01-02), railroads (SIC 40), the Postal Service (SIC 43), private households (SIC 88), and pension, health, and welfare funds with at least 100 employees (SIC 6371). The data show that about 61 percent of firms have fewer than five employees (compared with 64 percent of the survey population), 38 percent were in business and professional services (compared with 43 percent), and 21 percent were in retail trade (compared with 19 percent). In addition, about 83 percent were located in urban areas (compared with about 80 percent) and 21 percent were in the Northeast, 23 percent in the Midwest, 32 percent in the South, and 23 percent in the West (compared with 19 percent, 22 percent, 33 percent, and 27 percent respectively).

Sampling was done according to a two-stage stratified random design. In the first stage, the sample was stratified by number of employees, Census division, and urban/rural status. Because larger small businesses (those with twenty or more employees) account for a small proportion of the target population, those firms were sampled at a rate greater than their proportion in the population to ensure a large enough sample to permit comparisons with smaller small businesses. A sample of nearly 40,000 firms was selected in this first stage, representing 7.5 mil- lion firms in the Market Identifier file; 27,000 completed the screening process, and nearly 20,000 were determined to be part of the target population, representing about 5.3 million firms. ${ }^{27}$ Besides verifying eligibility, the screening was designed to collect information on minority ownership (where a minorityowned firm was defined as one more than 50 percent owned by individuals who are Hispanic, Latino, or of Spanish descent; Asian, Native Hawaiian, or other Pacific Islander; black; or American Indian or Alaska Native), information not reliably available in the Dun \& Bradstreet file. ${ }^{28}$

In the second stage, the sample was stratified by number of employees, Census division, urban/rural status, and minority ownership (black, Asian, Hispanic, and "other"). Like relatively larger small businesses, minority-owned firms account for only a small percentage of the population of small businesses but are of special interest to researchers and policymakers. For these reasons, such firms were oversampled to ensure that their numbers would be sufficient to allow for statistical comparisons between them and other firms.

Of the 20,000 firms determined to be part of the target population, only 11,000 were asked to participate in the main interview (the second stage), as the screened sample contained a surplus of small, nonminority-owned firms. Of these 11,000 firms, 3,561 completed the main interview, for a response rate of 33 percent. ${ }^{29}$ The results presented in this article have been weighted to allow for different rates of sampling and different rates of response. The estimates provided are representative of the eligible portion of the Dun \& Bradstreet frame.

Before the screening, firms were mailed a brochure describing the survey. They were contacted by telephone and asked to complete a short computer-

27. Of the approximately 13,000 firms that did not complete the screening process, about 6,000 declined to participate. Of the remainder, the majority could not be contacted for various reasons.

28. John D. Wolken, Catherine Haggerty, Karen Grigorian, and Rachel Harter, "The 1998 Survey of Small Business Finances: Sampling and Level of Effort Associated with Gaining Cooperation from Minority-Owned Businesses," paper presented at the International Conference on Establishment Surveys II, June 2000, Buffalo, New York (forthcoming in ICES II conference proceedings).

29. The response rate for the 1993 survey was 47 percent. The decline in response rate is generally consistent with a decline in response rates in many recent scientific surveys, including those of the U.S. Census Bureau. There are several possible reasons for the lower rate. Interviews were conducted several months after screening, allowing time for businesses to become defunct and also requiring that businesses cooperate twice instead of once. Also, many of the main interviews were completed near January 1, 2000, when many businesses were busy and therefore less willing to participate. 
A.1. Characteristics of small businesses, distributed by selected category of firm, 1998

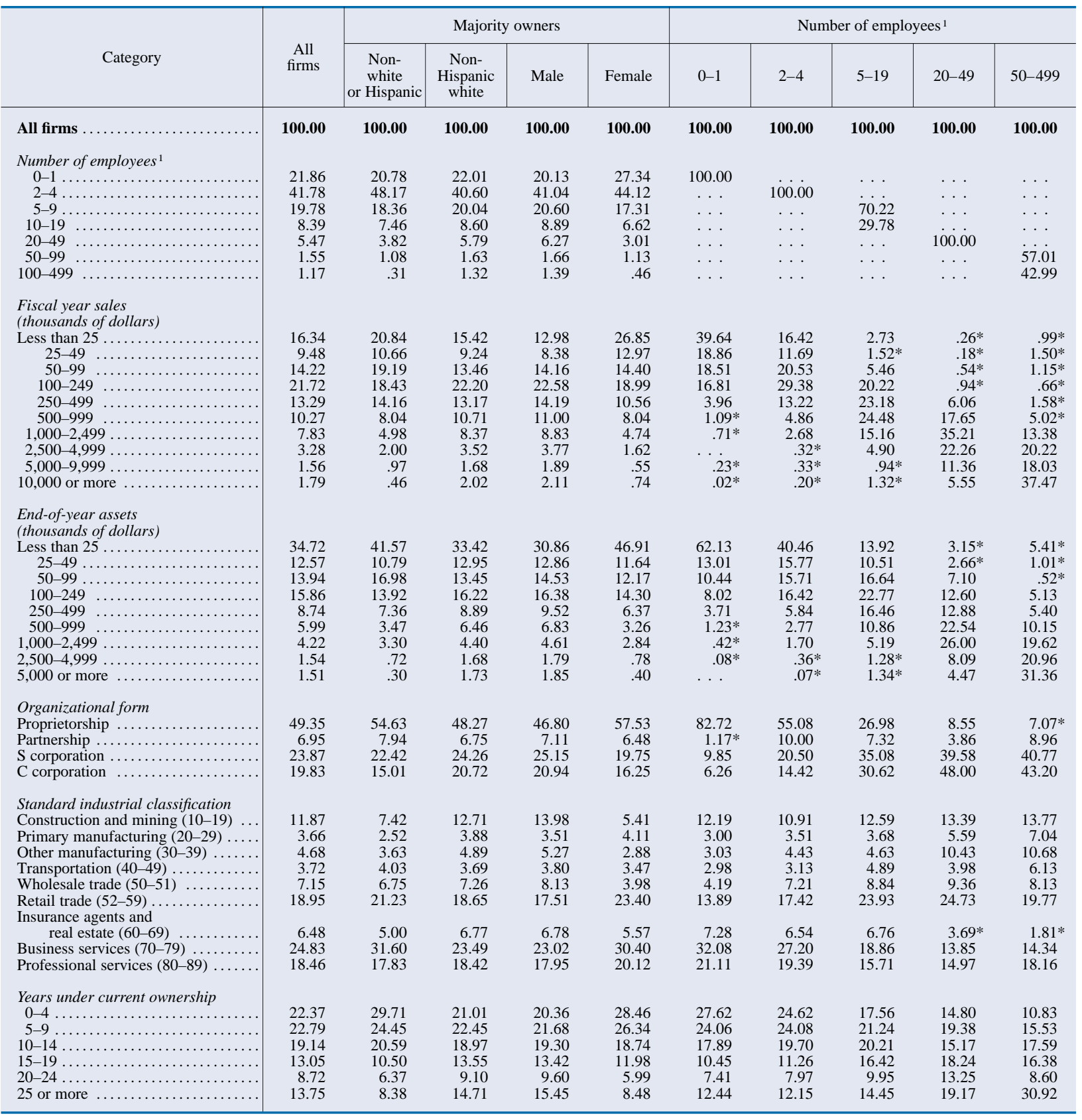

For notes, see end of table.

assisted telephone interview to verify their eligibility. The screening interview took about five minutes. The total time required by NORC to contact firms and administer all interviews, whether completed or not, averaged about thirty-nine minutes per completed screening interview. ${ }^{30}$

30. For both the screening and the main interviews, the total time per completed interview is the total number of interview hours for all cases, whether the interview was completed or not, divided by the number of completed cases.
Firms selected for the main interview were sent further information about the survey and a customized worksheet to help them consult their records before the interview. The worksheet requested financial data for the firm and information about the financial services used by the firm and the sources of those services. The worksheet differed according to the firm's legal organizational form and directed respondents to the appropriate lines on their tax forms. The main interview, also a computer assisted 
A.1.-Continued

\begin{tabular}{|c|c|c|c|c|c|c|c|c|c|c|}
\hline \multirow[b]{2}{*}{ Category } & \multirow[b]{2}{*}{$\begin{array}{c}\text { All } \\
\text { firms }\end{array}$} & \multicolumn{4}{|c|}{ Majority owners } & \multicolumn{5}{|c|}{ Number of employees ${ }^{1}$} \\
\hline & & \begin{tabular}{|c|} 
Non- \\
white \\
or Hispanic
\end{tabular} & $\begin{array}{l}\text { Non- } \\
\text { Hispanic } \\
\text { white }\end{array}$ & Male & Female & $0-1$ & $2-4$ & $5-19$ & $20-49$ & $50-499$ \\
\hline \multicolumn{11}{|l|}{ Census region of main office } \\
\hline Northeast $\ldots \ldots \ldots \ldots \ldots$ & 18.90 & 15.86 & 19.31 & 19.65 & 16.66 & 20.92 & 19.63 & 17.20 & 15.09 & 16.75 \\
\hline New England & 5.21 & $.97 *$ & 5.87 & 5.00 & 5.90 & 5.98 & 5.28 & 4.46 & 6.48 & 3.29 \\
\hline Middle Atlantic & 13.69 & 14.88 & 13.44 & 14.65 & 10.75 & 14.94 & 14.35 & 12.75 & 8.61 & 13.46 \\
\hline Midwest & 21.80 & 10.44 & 23.77 & 22.28 & 20.37 & 19.51 & 22.00 & 22.36 & 26.61 & 21.42 \\
\hline East North Central & 14.56 & 7.23 & 15.79 & 15.27 & 12.41 & 12.84 & 14.45 & 15.91 & 16.11 & 12.67 \\
\hline West North Central & 7.24 & 3.21 & 7.98 & 7.02 & 7.96 & 6.68 & 7.55 & 6.45 & 10.50 & 8.75 \\
\hline South & 32.71 & 37.01 & 32.07 & 32.69 & 32.59 & 32.36 & 33.50 & 32.31 & 29.37 & 34.26 \\
\hline South Atlantic & 16.88 & 19.44 & 16.45 & 16.59 & 17.72 & 17.59 & 16.99 & 16.10 & 15.89 & 19.68 \\
\hline East South Central & 5.47 & 2.43 & 6.03 & 5.76 & 4.46 & 3.70 & 5.41 & 7.08 & 5.35 & 4.43 \\
\hline West South Central & 10.35 & 15.14 & 9.59 & 10.34 & 10.41 & 11.07 & 11.10 & 9.12 & 8.13 & 10.16 \\
\hline West & 26.59 & 36.69 & 24.85 & 25.38 & 30.38 & 27.21 & 24.88 & 28.13 & 28.93 & 27.56 \\
\hline Mountain & 6.63 & 7.05 & 6.54 & 6.88 & 5.88 & 6.56 & 5.62 & 8.05 & 7.87 & 5.55 \\
\hline Pacific .... & 19.96 & 29.64 & 18.31 & 18.50 & 24.50 & 20.65 & 19.26 & 20.08 & 21.06 & 22.01 \\
\hline \multicolumn{11}{|l|}{ Urbanization at main office } \\
\hline Urban..$\ldots \ldots \ldots \ldots \ldots$ & 79.91 & 89.63 & 78.19 & 79.80 & 80.33 & 81.91 & 78.86 & 79.42 & 80.37 & 84.33 \\
\hline Rural & 20.09 & 10.37 & 21.81 & 20.20 & 19.67 & 18.09 & 21.14 & 20.58 & 19.63 & 15.67 \\
\hline \multicolumn{11}{|l|}{ Number of offices } \\
\hline One ............ & 87.75 & 89.18 & 87.51 & 86.47 & 91.87 & 96.58 & 91.10 & 84.40 & 66.67 & 42.52 \\
\hline Two & 8.55 & 7.37 & 8.76 & 9.21 & 6.51 & 2.89 & 7.66 & 10.85 & 20.19 & 20.67 \\
\hline Three or more & 3.63 & 3.45 & 3.64 & 4.22 & 1.62 & $.53^{*}$ & 1.24 & 4.50 & 13.14 & 36.81 \\
\hline \multicolumn{11}{|l|}{ Sales area } \\
\hline Primarily within U.S. & 95.43 & 93.63 & 95.76 & 95.20 & 96.13 & 95.76 & 95.31 & 96.17 & 94.11 & 89.69 \\
\hline International or global & 4.51 & 6.37 & 4.16 & 4.71 & 3.87 & 4.24 & 4.69 & 3.66 & 5.58 & 10.31 \\
\hline \multicolumn{11}{|l|}{ Owners' participation } \\
\hline Owner management & 92.33 & 93.36 & 92.11 & 92.24 & 92.97 & 98.75 & 94.46 & 87.04 & 85.77 & 75.85 \\
\hline Hired management . & 7.52 & 6.64 & 7.72 & 7.70 & 6.79 & $1.25 *$ & 5.44 & 12.59 & 14.23 & 24.15 \\
\hline \multicolumn{11}{|l|}{ Race, ethnicity, and sex } \\
\hline Nonwhite or Hispanic & 14.60 & 100.00 & & 14.18 & 15.90 & 13.88 & 16.83 & 13.38 & 10.20 & 7.49 \\
\hline Non-Hispanic white & 84.88 & $\ldots$ & 100.00 & 85.25 & 83.72 & 85.48 & 82.48 & 86.30 & 89.80 & 92.20 \\
\hline White & 90.12 & 35.79 & 100.00 & 90.70 & 88.34 & 90.58 & 88.39 & 90.81 & 95.49 & 95.02 \\
\hline Black & 4.12 & 28.21 & $\ldots$ & 3.77 & 5.21 & 3.88 & 5.34 & 3.40 & $.55 *$ & 1.87 \\
\hline Asian or Pacific Islander & 4.38 & 29.97 & $\ldots$ & 4.14 & 5.05 & 3.86 & 4.49 & 4.90 & 3.74 & 2.71 \\
\hline American Indian or Alaska Native & .81 & 5.58 & $\cdots$ & .77 & $.95^{*}$ & $1.04 *$ & $1.02 *$ & $.52 *$ & $.22 *$ & $.10^{*}$ \\
\hline Hispanic ..... & 5.59 & 38.29 & & 5.78 & 5.03 & 5.27 & 6.47 & 4.78 & 5.68 & 2.88 \\
\hline Non-Hispanic & 94.10 & 61.51 & 100.00 & 93.85 & 94.85 & 94.59 & 92.96 & 95.06 & 94.32 & 97.12 \\
\hline Female & 24.32 & 26.48 & 23.98 & & 100.00 & 30.42 & 25.68 & 20.67 & 13.36 & 14.26 \\
\hline Male . & 71.88 & 68.48 & 72.41 & 95.14 & & 68.86 & 69.89 & 74.46 & 80.89 & 82.07 \\
\hline Ownership equally divided by sex & 3.67 & 4.90 & 3.49 & 4.86 & & $.73^{*}$ & 4.33 & 4.66 & 5.64 & 2.97 \\
\hline
\end{tabular}

telephone interview, took about forty minutes. However, the total time spent by NORC, including the time spent trying to contact and convert nonrespondents, averaged nearly seven hours per completed case. Most of the time it took to complete the interviews was spent establishing contact, setting appointments with business owners, reestablishing contact when interviews were broken off by respondents, and trying to persuade reluctant owners to complete the interview.

The information collected from each business fits into the following categories: demographics of the firm and its primary owner; the firm's use of financial services and the sources providing the services; applications for credit by the firm in the past three years; balance sheet data; and recent credit history of the firm and its owners. A public-use version of the data set and a user's manual will be posted on the Federal Reserve Board's web site after completion of data editing and other processing steps (www. federalreserve.gov/pubs/oss/oss3/nssbftoc.htm). 
A.1. Characteristics of small businesses, distributed by selected category of firm, 1998_Continued

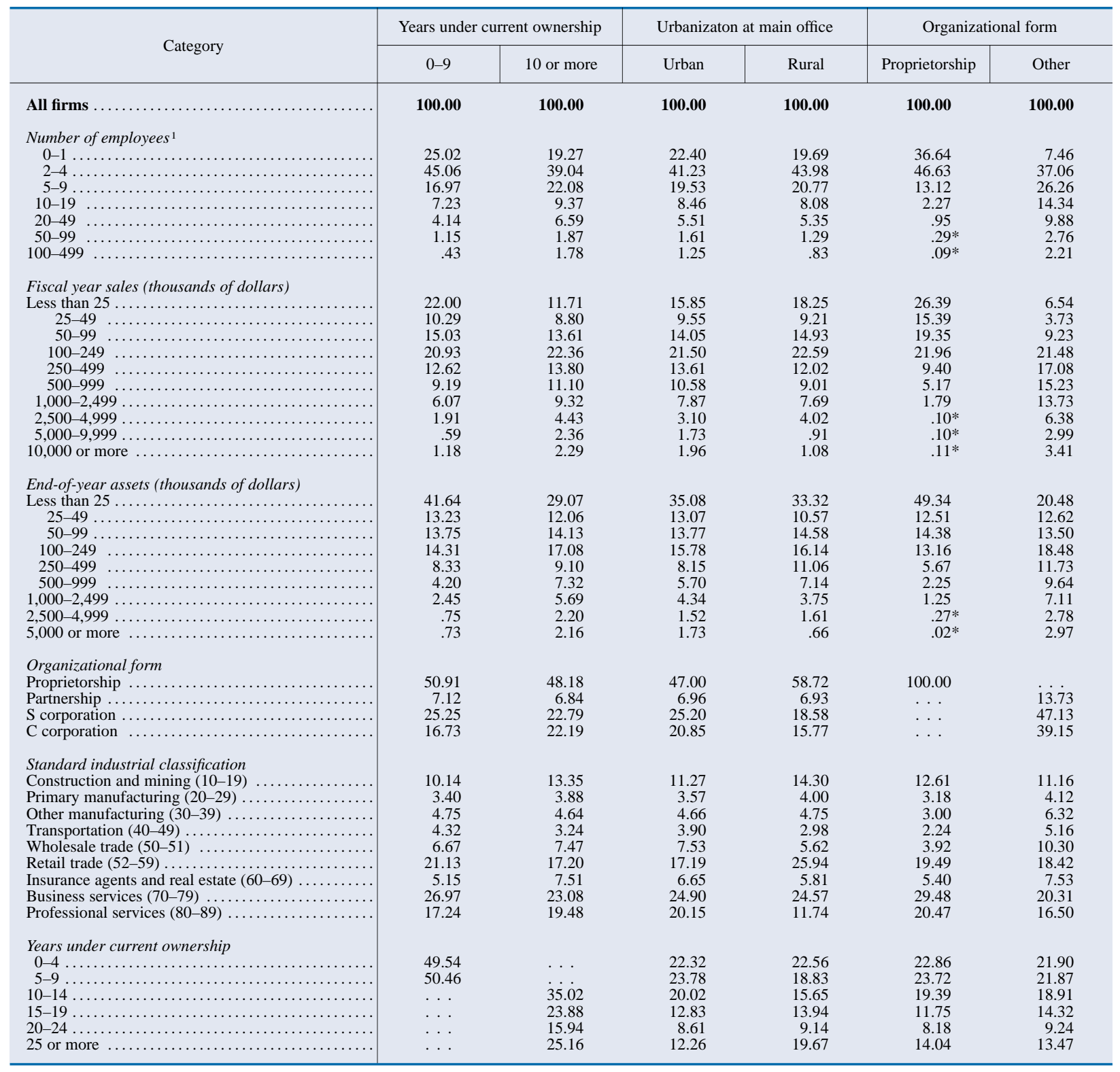


A.1.-Continued

\begin{tabular}{|c|c|c|c|c|c|c|}
\hline \multirow{2}{*}{ Category } & \multicolumn{2}{|c|}{ Years under current ownership } & \multicolumn{2}{|c|}{ Urbanizaton at main office } & \multicolumn{2}{|c|}{ Organizational form } \\
\hline & $0-9$ & 10 or more & Urban & Rural & Proprietorship & Other \\
\hline \multicolumn{7}{|l|}{ Census region of main office } \\
\hline Northeast $\ldots \ldots \ldots \ldots \ldots$ & 16.98 & 20.46 & 21.01 & 10.52 & 18.91 & 18.89 \\
\hline New England & 5.31 & 5.15 & 5.45 & 4.29 & 5.47 & 4.97 \\
\hline Middle Atlantic & 11.67 & 15.31 & 15.56 & 6.23 & 13.45 & 13.92 \\
\hline Midwest & 21.31 & 22.26 & 19.40 & 31.34 & 20.30 & 23.25 \\
\hline East North Central & 14.35 & 14.77 & 13.92 & 17.09 & 12.82 & 16.25 \\
\hline West North Central & 6.97 & 7.49 & 5.48 & 14.25 & 7.48 & 7.01 \\
\hline South & 34.91 & 30.82 & 31.21 & 38.65 & 31.12 & 34.26 \\
\hline South Atlantic & 19.41 & 14.77 & 17.21 & 15.57 & 14.16 & 19.54 \\
\hline East South Central & 5.34 & 5.60 & 3.99 & 11.39 & 5.12 & 5.82 \\
\hline West South Central & 10.16 & 10.44 & 10.01 & 11.69 & 11.84 & 8.90 \\
\hline West & 26.79 & 26.46 & 28.38 & 19.49 & 29.67 & 23.60 \\
\hline Mountain & 6.66 & 6.57 & 5.89 & 9.56 & 5.94 & 7.30 \\
\hline Pacific ... & 20.13 & 19.88 & 22.49 & 9.93 & 23.72 & 16.30 \\
\hline \multicolumn{7}{|l|}{ Urbanization at main office } \\
\hline 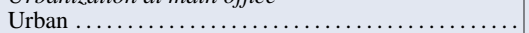 & 81.59 & 78.54 & 100.00 & & 76.10 & 83.63 \\
\hline Rural $\ldots \ldots \ldots \ldots$ & 18.41 & 21.46 & $\ldots$ & 100.00 & 23.90 & 16.37 \\
\hline \multicolumn{7}{|l|}{ Number of offices } \\
\hline One ............ & 89.44 & 86.41 & 87.43 & 89.00 & 93.19 & 82.45 \\
\hline Two ........... & 7.91 & 9.10 & 8.70 & 7.98 & 5.65 & 11.38 \\
\hline Three or more & 2.60 & 4.49 & 3.78 & 3.02 & 1.16 & 6.03 \\
\hline \multicolumn{7}{|l|}{ Sales area } \\
\hline Primarily within U.S. & 94.47 & 96.30 & 94.94 & 97.38 & 96.86 & 94.04 \\
\hline International or global & 5.53 & 3.67 & 5.00 & 2.54 & 3.14 & 5.84 \\
\hline \multicolumn{7}{|l|}{ Owners' participation } \\
\hline Owner management . & 93.10 & 91.84 & 91.95 & 93.83 & 96.15 & 88.60 \\
\hline Hired management .. & 6.83 & 8.11 & 7.92 & 5.96 & 3.85 & 11.11 \\
\hline \multicolumn{7}{|l|}{ Race, ethnicity, and sex of majority owners } \\
\hline Nonwhite or Hispanic $\ldots \ldots \ldots \ldots \ldots \ldots \ldots$ & 17.51 & 12.24 & 16.37 & 7.54 & 16.16 & 13.08 \\
\hline Non-Hispanic white . & 81.68 & 87.46 & 83.04 & 92.17 & 83.01 & 86.69 \\
\hline White & 87.92 & 91.90 & 89.11 & 94.13 & 88.84 & 91.36 \\
\hline Black & 4.96 & 3.44 & 4.53 & 2.47 & 4.88 & 3.38 \\
\hline Asian or Pacific Islander & 5.25 & 3.66 & 5.05 & 1.70 & 4.54 & 4.21 \\
\hline American Indian or Alaska Native ... & $.98^{*}$ & $.68^{*}$ & .64 & $1.50^{*}$ & $.90^{*}$ & $.73 *$ \\
\hline Hispanic $\ldots \ldots \ldots$ & 6.64 & 4.74 & 6.45 & 2.18 & 6.15 & 5.04 \\
\hline Non-Hispanic $\ldots$. & 92.84 & 95.12 & 93.23 & 97.54 & 93.43 & 94.75 \\
\hline Female ......... & 29.51 & 20.11 & 24.44 & 23.82 & 28.34 & 20.39 \\
\hline Male...$\ldots \ldots \ldots \ldots$ & 66.52 & 76.30 & 71.79 & 72.28 & 71.66 & 72.11 \\
\hline Ownership equally divided by sex $\ldots \ldots \ldots \ldots \ldots$ & 3.83 & 3.55 & 3.67 & 3.70 & $\ldots$ & 7.25 \\
\hline
\end{tabular}

1. See text table 1 , note 1 .

... Not applicable.

* Fewer than fifteen firms in this category reported this characteristic, too small a number on which to base a reliable statistic. 